\title{
Lifestyle Behavioral Patterns Among Male and Female University Students of Pakistan
}

\author{
Aqsa Mohsin (Corresponding author) \\ B.S Honors Home Economics \\ Department of Human Development and Family Studies \\ College of Home Economics Lahore, Pakistan \\ E-mail: aqsa.mohsin1@gmail.com
}

Nuzhat Firdous

Department of Human Development and Family Studies, College of Home Economics Lahore, Pakistan

\author{
Received: March 14, 2018 Accepted: April 4, 2018 Published: April 23, 2018 \\ doi:10.5296/jad.v4i1.13050 URL: https://doi.org/10.5296/jad.v4i1.13050
}

\begin{abstract}
The existing study was conducted to analyze lifestyle behaviors among universities students. The sample of 200 students ( 100 male and 100 females) were selected through the procedure of simple random sampling. The tool of data collection was self - administrative based on the Lifestyle questionnaire and Lifestyle Assessment questionnaire from queen's university peer mentor program. The data was statistically analyzed by applying $t$ - test to find the difference between lifestyle behavioral patterns of male and female students and difference between lifestyle behavioral patterns of public and private university students. Results showed that there is difference between male and female lifestyle in some aspects of behavioral patterns, particularly their physical activity and weight management. There is also difference between the public and private university student's lifestyle behavioral patterns. Specifically, in stress management and living style such as brand conscious.
\end{abstract}

Keywords: Lifestyle, university student, physical activity, BMI, nutritional habits 


\section{Introduction}

Every observer is confident to precise their opinion about lifestyle issues (Thirlaway, 2009). Students find themselves in a new, challenging and competitive environment, most of them are experiencing independence and responsibility for the first time in their lives. During university time they consequently adopt new health behaviors and there may be a risk that they continue with unhealthy lifestyle choices that were established during their university years, which makes them a risk group not only during these years but for the rest of their lives (Schmidt, 2012).

People of any age group have a better quality of life when they improve and participate in health-promoting behaviors into their lifestyle (Wright, 2012) Lifestyle of university students may have control on their future lives and wellbeing (Schmidt 2012). Healthy lifestyle behaviors are those behaviors that establish responsibility for one's own health, taking part in physical activity, having adequate nutritional intake, understanding self-actualization, establishing interpersonal relations, and learning how to manage stress. (Wright, 2012). Lifestyle behaviors are usually designed during adulthood (Schmidt 2012). Nutrition, physical activity, time and stress management have been familiar as some of the major behaviors to target for analysis in the students and teen age group, early stage prevention in life is key principle to living healthy life in later years when the risks for disease are so much higher (Wright, 2012).

\subsection{Objectives}

To explore about different lifestyles behavioral patterns among students.

To compare lifestyle behavioral pattern between male and female students.

To compare students' lifestyle behavioral pattern between public and private University.

To find out the body description in the context to BMI.

\subsection{Statement of Problem}

The current study will try to investigate the individual lifestyle behavioral patterns among university students. Moreover different lifestyle behaviors including health (physical activity, fitness, nutritional habits, sleep patterns, stress and time management skills) of students will be explore from different universities of Pakistan.

\section{Literature Review}

Every individual has different way and style of living. Yang et al. (2015) a cross sectional study of lifestyle behavior related to health was contacted with the sample of 5484 Shanghai workers. The $37 \%$ workers have healthy lifestyle others belongs to unhealthy lifestyle. Mostly male who associated from small workplace and those who have working hours more than 8 to 11 in both male and female have unhealthy lifestyle. Those workers have less earning they were also associated from unhealthy lifestyle. Schubert et al. (2011) conduct research effect of diet and exercise on weight and body composition. The $4-\operatorname{arm}$ randomized scale use for this research, 439 overweight to obese women participate for this study. It 
determine the effects of diet, exercise (D), exercise (E), and the mixture of both interpositions $(\mathrm{D}+\mathrm{E})$, lifestyle change control (C) on amendment in body weight and structure. Lifestyle change relating diet, exercise, or both mutual over 1 year increases body weight and adiposity among women, with the highest change arising from the collective involvement.

Ceschini et al. (2015) was to designate the physical activity level and linked factors among students attending evening classes in public and private schools in an area of the city of Sao Paulo. The sample was collected of 1,844 adolescents of both sex's male and female aged between 15 - 20 years. Three public and private schools in the city of Sao Paulo were visited. International Physical Activity Questionnaire that classifies physical activity level used to measured daily physical activity level. The prevalence of physically active youngsters was 36.1\%. "Questionnaire on Health and Nutrition Conditions (2004)" used for data collection. The research concluded that adolescents attending evening classes do not meet the minimum approvals of physical activity related with health promotion. Lemma et al. (2012) evaluate the sleep habits, sleep patterns, and sleep quality amongst Ethiopian college students. Total of 2,230 undergraduate students accomplished a self - administered inclusive questionnaire which collected information about sleep grumbles, socio - demographic and lifestyle characteristics. Total $52.7 \%$ of students were confidential as having poor sleep quality. The $51.8 \%$ males and $56.9 \%$ females. Findings of the current study establish the high popularity of poor sleep quality and its relationship with stimulating use between college students.

Tamar Shochat, (2012) work on the lifestyle impact and technology development on sleep. Technical advancements have manage to pay for modern society with 24 - hour work processes, Additional behavioral lifestyle factors connected with poor sleep include weight gain, inadequate physical exercise and ingesting of materials such as caffeine, alcohol and nicotine. The result highlight current lifestyle tendencies that have been presented in logical surveys to be related with sleep patterns, sleep time period and sleep quality. Interpositions expected at improving sleep turbulences that are connected to specific behavioral lifestyle habits are only establish to emerge. (Sabbah et al. 2013) Observing health related quality of life (HRQoL) in larger public university students. SF - 36 health survey questionnaire was used for this study, 282 students participate in this research. The $27 \%$ population expressively current smokers. Female students had poor HRQoL than the male students specifically in mental health scale. Concluded that the majority of youth HRQoL is pretentious by behavioral characteristics.

Kuchma (2012) conduct the research on effect of modern student's lifestyle on the physical development, studying the subtleties of the physical development of children and adolescents during the first era of the 21 st century, children were belongs to age group of $11-13$ years old boys and 9 years old girls. It was found that $39.8 \%$ of the girls and $36.4 \%$ of the boys consumed $6-15$ hours per week on the computer, whereas $6.2 \%$ and $13.1 \%$, spent more than 30 hours a week. So it is concluded that the changes in the sizes of the body structure of modern students are most obviously apparent in the growth of leg lengths.

Lifestyle behavioral patterns are interlinked with each other. It is observed that physical activity and food intake play role in BMI and body description. In the light of the review of 
literature it is concluded that these all variables are inter contacted. Each variable related to others so unhealthy lifestyle behaviors effect the individual. Healthy lifestyle helps to promote healthy nutritional intake, good body descriptions and prevented from different disease

\section{Methodology}

The purpose of this study to investigate the different lifestyle behaviors of students. This study tried to find out the difference between lifestyle behaviors of private and public university students. It is a quantitative research and a survey method was carried out for the purpose. The population of the study was adolescents aged 20 to 25 years from public or private sector universities. The universities selected for this study was University of the Punjab (PU) as public and University of Central Punjab (UCP) as private university. Sample selected for this study was of 200 total students. The 100 students were chosen from public university such as Punjab University, and 100 students were selected from private university as University Of Central Punjab. The researcher selected gender wise distribution in the sample is proportionate with the population (50 males and 50 females). The researcher selected students through simple random sampling method.

\subsection{Instrument Development}

Researcher was used the questionnaire as a tool for investigation techniques. Due to ease in analysis and interpretations, closed ended questions used in the questionnaire. The researcher keeping in mind some problem related to student's lifestyle behaviors and cultural values while developing questionnaire. The questionnaire develop in such way the maximum information could be gathered. The questionnaire, comprised on 8 sections regarding lifestyle. The questionnaire was self-developed by researcher on the basis of literature review. There was 40 close ended questions stated in very simple English. A well-structured questionnaire based on Multiple Choice questionnaire. Each questions required and evaluation which was based upon 3-point Liker scale.

\subsection{Data Collection}

A pre-test was conducted before the actual data collection from respondents. For this purpose, the researcher select 20 students and select the Punjab University, the questionnaire was equally distributed gender wise. By the help of this pilot study, the researcher was able to know about some short amendments in the questionnaire. Some questions were also added after gained better understanding through pre-test. Pre-testing provide help to get more accurate responses from respondents. The research commenced from December 2015. Pilot-study was conducted in January 2016 and final data collection was done in March 2016.

\section{Data Analysis}

The collected data was analyzed by the using the SPSS (Statistical package for Social Sciences) software version 20. Independent sample t-test was conducted to see the difference between male and female student's lifestyle behavioral patterns and the difference between the public and private universities student's lifestyle behavioral patterns and present in the 
form of tables and graphs and final results are followed by interpretations.

Table 4.1. Frequency and percentage of family system and prefer family system

\begin{tabular}{|c|c|c|c|c|}
\hline \multirow[b]{2}{*}{ Variables } & \multicolumn{2}{|c|}{ Joint } & \multicolumn{2}{|c|}{ Nuclear } \\
\hline & f & $\%$ & f & $\%$ \\
\hline Family system & 99 & 49.5 & 101 & 50.5 \\
\hline Prefer system & 93 & 46.5 & 107 & 53.5 \\
\hline
\end{tabular}

\section{Interpretation}

Out of total 200 students $99(49.5 \%)$ students have joint family system. The 93 (46.5\%) students of them prefer to live in joint family system. The $101(50.5 \%)$ students out of 200 students, have nuclear family system and 107 (53.5\%) students of them wants to live in nuclear family system. So it is concluded that majority of students prefer to have nuclear family system.

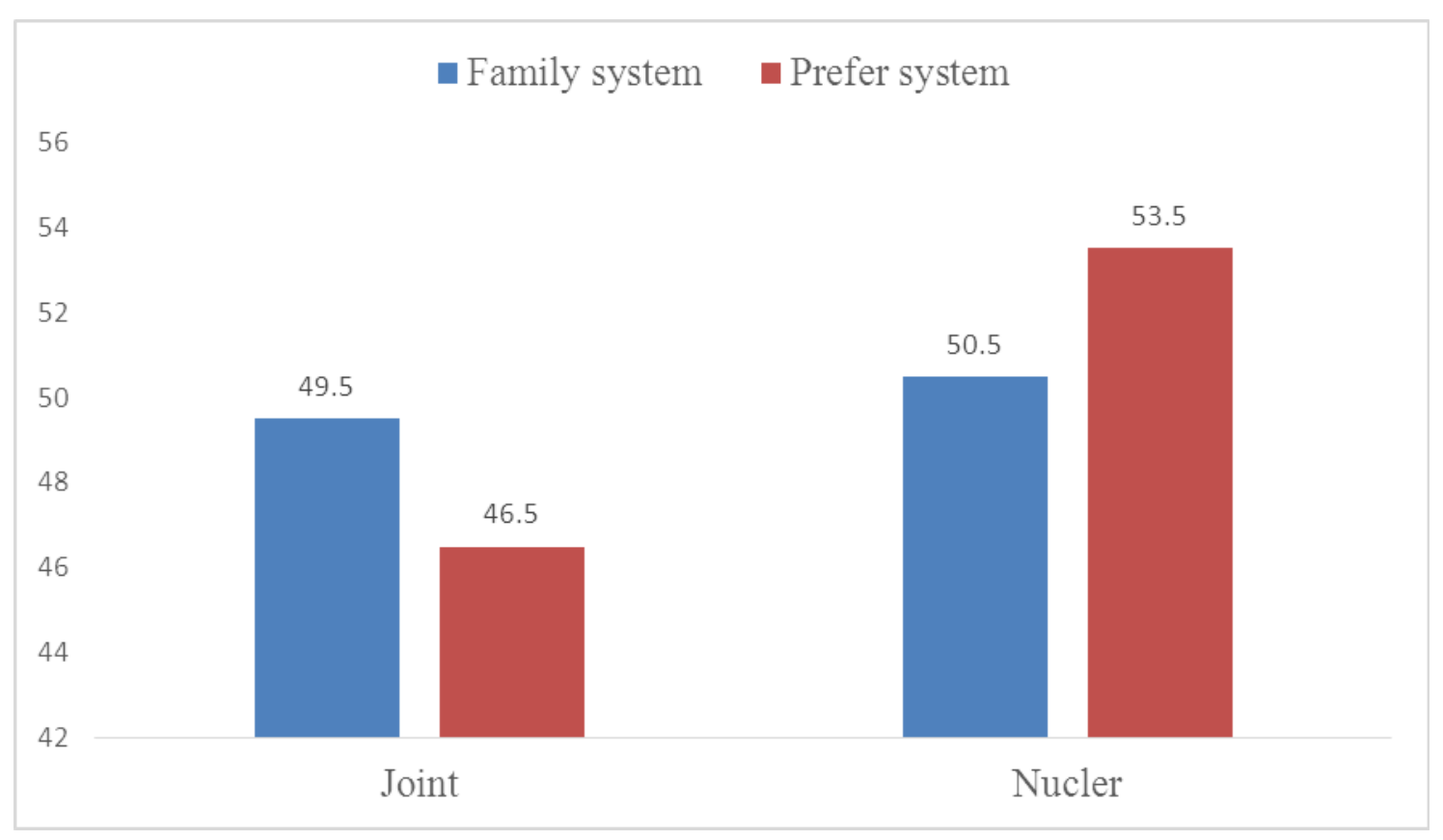

Figure 4.1. 


\section{Macrothink}

Table 4.2. Association between present family system and prefer family system

\begin{tabular}{|c|c|c|c|c|c|c|c|c|c|c|}
\hline & & & \multicolumn{6}{|c|}{ Present family system } & \multirow{3}{*}{ Chi-square } & \multirow{3}{*}{$\mathbf{P}$} \\
\hline & & & \multicolumn{2}{|c|}{$\begin{array}{l}\text { Joint } \\
\end{array}$} & \multicolumn{2}{|c|}{ Nuclear } & \multicolumn{2}{|c|}{ Total } & & \\
\hline & & & $\bar{f}$ & $\%$ & $\mathbf{f}$ & $\%$ & f & $\%$ & & \\
\hline \multirow{3}{*}{$\begin{array}{l}\text { Prefer } \\
\text { system }\end{array}$} & \multirow[t]{3}{*}{ family } & Joint & 68 & 68.7 & 25 & 24.8 & 93 & 46.5 & \multirow[t]{3}{*}{39.71} & \multirow[t]{3}{*}{$<.001$} \\
\hline & & Nuclear & 31 & 31.3 & 76 & 75.2 & 107 & 53.5 & & \\
\hline & & Total & 99 & 100 & 101 & 100 & 200 & 100 & & \\
\hline
\end{tabular}

\section{Interpretation}

The 99 students of total have joint family system and 101 students have nuclear family system from 200 students. The $31(31.3 \%)$ out of 99 students prefer nuclear family system and $68(68.7 \%)$ out of 99 students prefer same system. The $25(24.8 \%)$ of 101 students prefer joint family system and $76(75.2 \%)$ of 101 students prefer same system. It is concluded that the students wanted to change from joint family to nuclear family system.

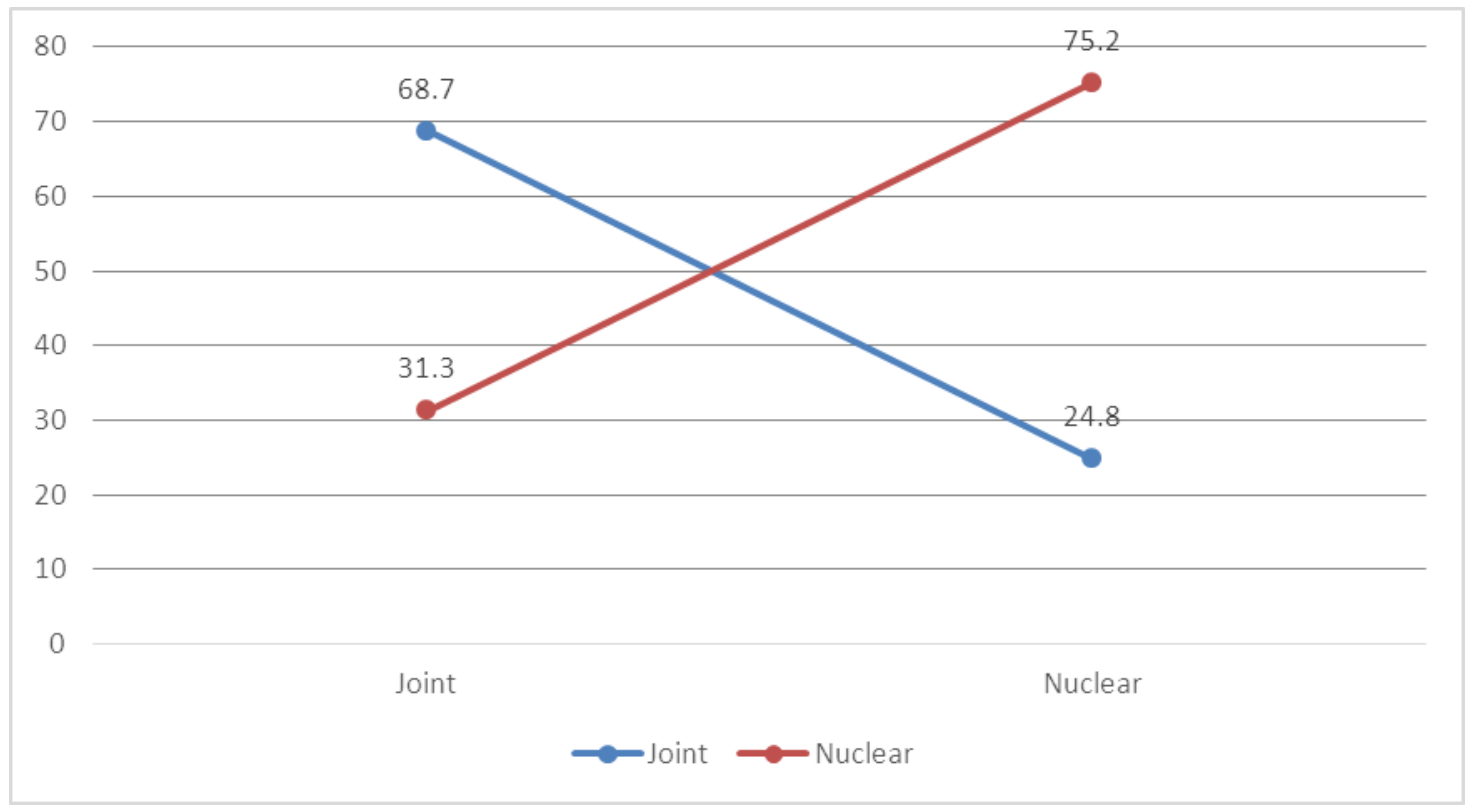

Figure 4.2. 
Table 4.3. Frequency and percentage of daily meal

\begin{tabular}{lllllll}
\hline \multirow{2}{*}{ Variable } & $1-2$ & \multicolumn{3}{c}{$3-4$} \\
\cline { 2 - 7 } & $\mathrm{f}$ & $\%$ & $\mathrm{f}$ & $\%$ & $\mathrm{f}$ & $\%$ \\
\hline Daily meal & 62 & 31.0 & 109 & 54.5 & 29 & 14.5 \\
\hline
\end{tabular}

\section{Interpretations}

Out of 200 students $62(31 \%)$ students consume 1-2 meals per day, 109 (54\%) students consume 2-3 meals per day while other 29 (14\%) students consume per day. So it is concluded that mostly students consume 2-3 meals per day.

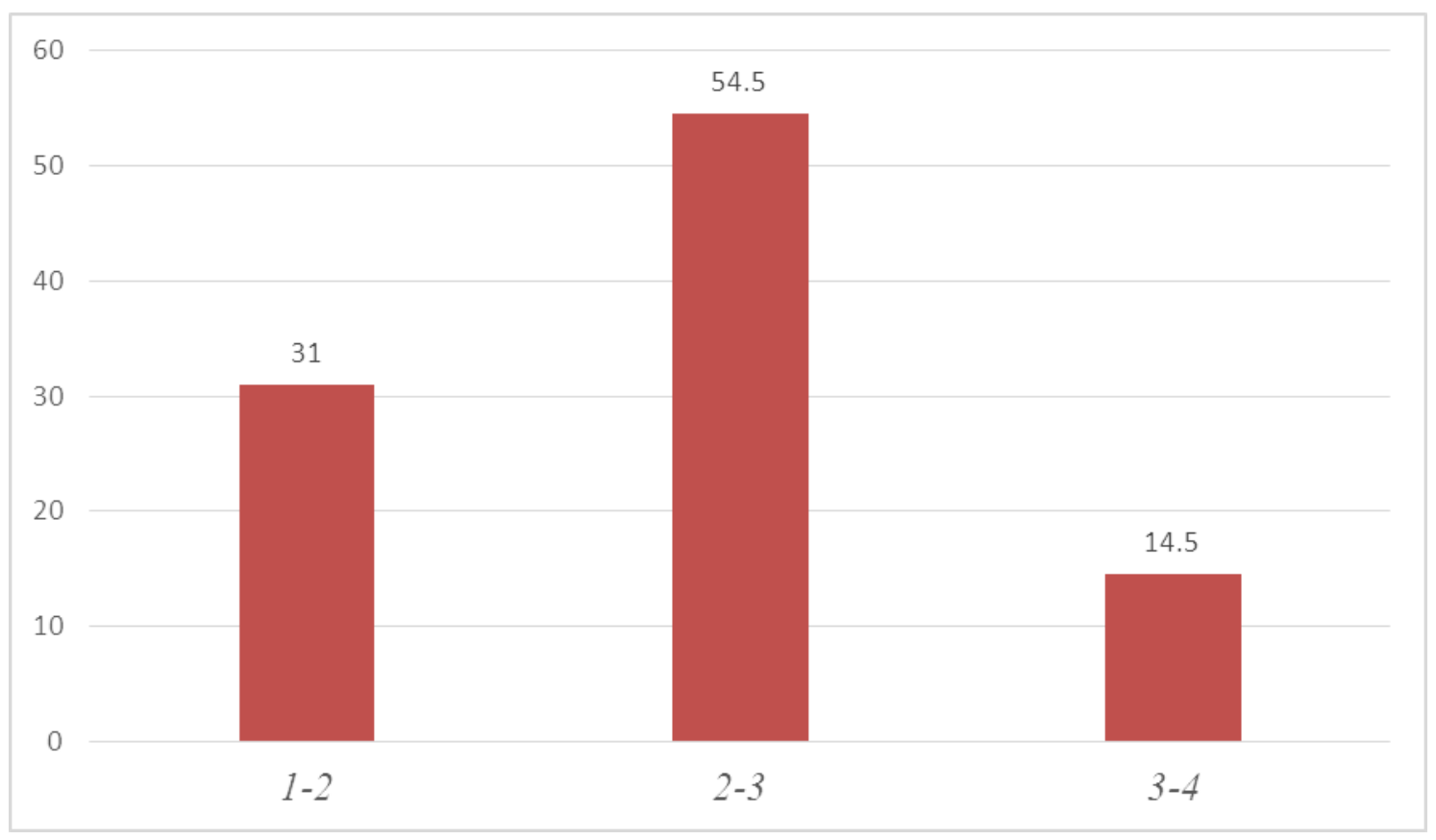

Figure 4.3.

Table 4.4. Frequency and percentage of weight reduce

\begin{tabular}{lllllll}
\hline \multirow{2}{*}{ Variable } & \multicolumn{2}{l}{ Gym } & \multicolumn{2}{c}{ Normal Diet \& exercise } & \multicolumn{2}{c}{ Skipping meal } \\
\cline { 2 - 7 } & f & $\%$ & f & $\%$ & f & $\%$ \\
\hline Reduce weight & 34 & 17.0 & 146 & 73.0 & 20 & 10.0 \\
\hline
\end{tabular}

\section{Interpretation}

Out of total 200 students $34(17 \%)$ students wanted to reduce their weight to do gym. Other 


\section{Macrothink}

Journal of Asian Development

ISSN 2377-9594 2018, Vol. 4, No. 1

$146(73 \%)$ students reduce their weight through normal diet and exercise. Only $20(10 \%)$ students wanted to reduces their weight through skipping meal. So it is concluded that $73 \%$ students want to reduce their weight through normal diet and exercise.

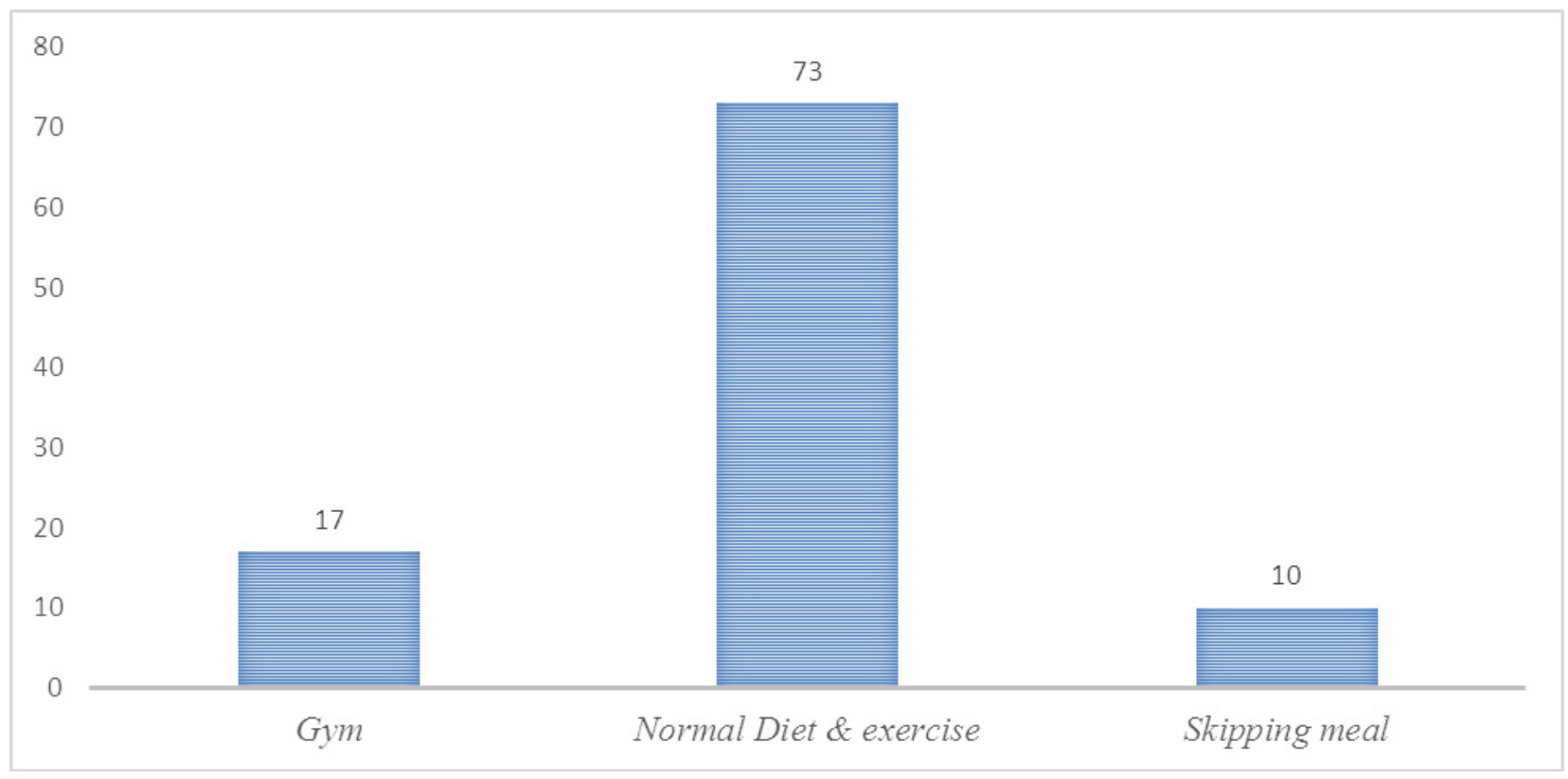

Figure 4.4.

Table 4.5. Frequency and percentage of sleep

\begin{tabular}{llllllc}
\hline \multirow{2}{*}{ Variable } & \multicolumn{2}{l}{$\mathbf{6 - 8}$ hours } & \multicolumn{2}{c}{$\mathbf{8 - 9}$ hours } & & \multicolumn{2}{c}{$\mathbf{9 - 1 0}$ hours } \\
\cline { 2 - 7 } & f & $\%$ & f & $\%$ & f & $\%$ \\
\hline Sleep & 128 & 64.0 & 54 & 27.0 & 24 & 12.0 \\
\hline
\end{tabular}

\section{Interpretation}

Out of total 200 students 128 (64\%) students get 6 to 8 hours sleep per night. Other 54 (27\%) students get 8 to 9 hours sleep per night. Only $24(12 \%)$ students get 9 to 10 hours sleep per night. It is concluded that most of the students get 6 to 8 hours sleep per night. 


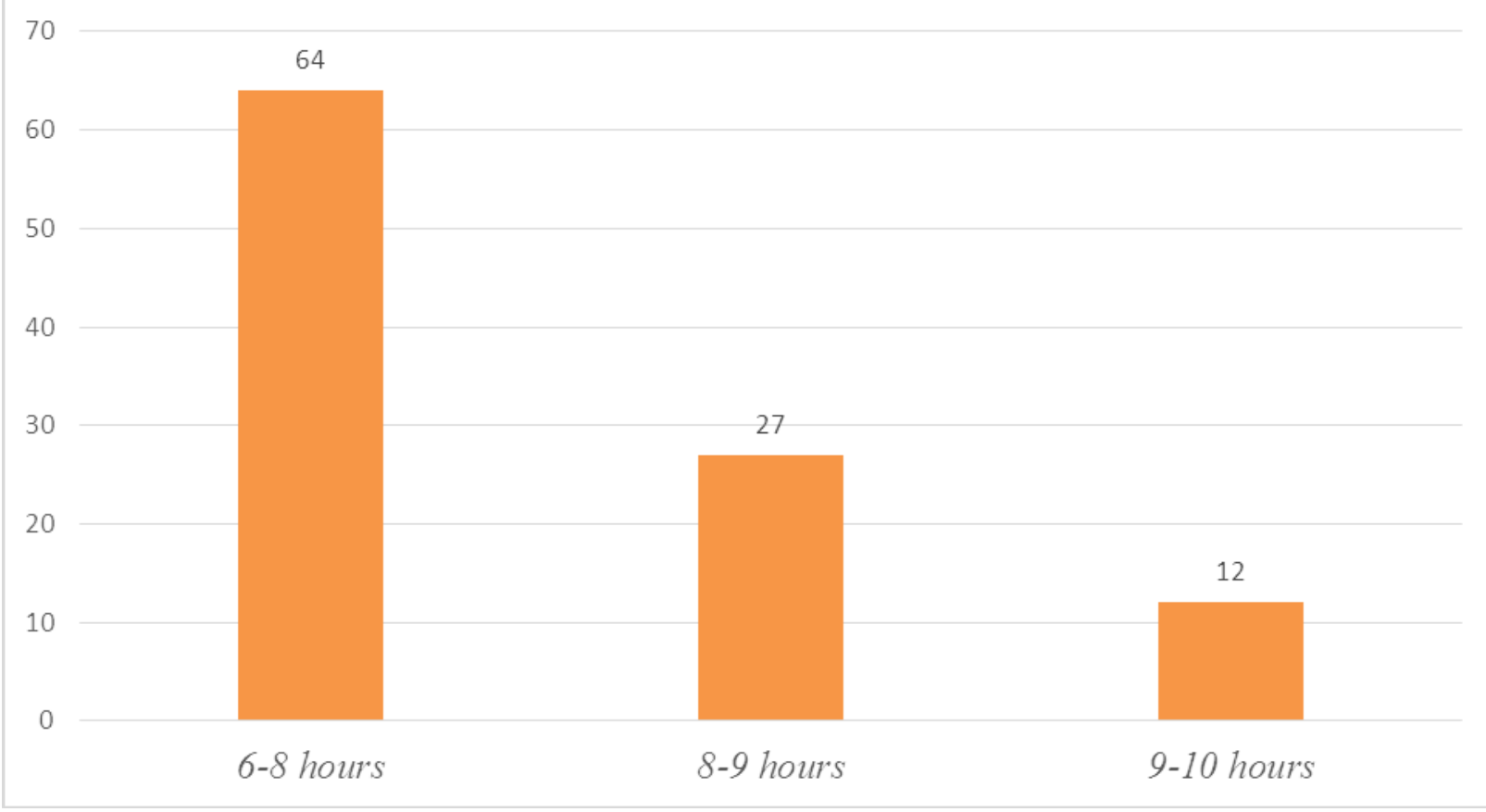

Figure 4.5.

Table 4.6. Frequency and percentage of major source of stress

\begin{tabular}{lllllll}
\hline \multirow{2}{*}{ Variable } & \multicolumn{2}{l}{ Peer pressure } & \multicolumn{2}{c}{ Family behavior } & \multicolumn{2}{c}{ Study burden } \\
\cline { 2 - 7 } & f & $\%$ & f & $\%$ & f & $\%$ \\
\hline Major source & 43 & 21.0 & 55 & 27.0 & 102 & 51.0 \\
\hline
\end{tabular}

\section{Interpretation}

Out of 200 total students $43(21 \%)$ students have peer pressure as their major sources of stress. Other $55(27 \%)$ students have family behavior as their major source of stress and 102 (51\%) students have study burden as their major source of stress. So it is concluded that mostly students have study burden as major source of stress. 


\section{Macrothink}

\section{0}

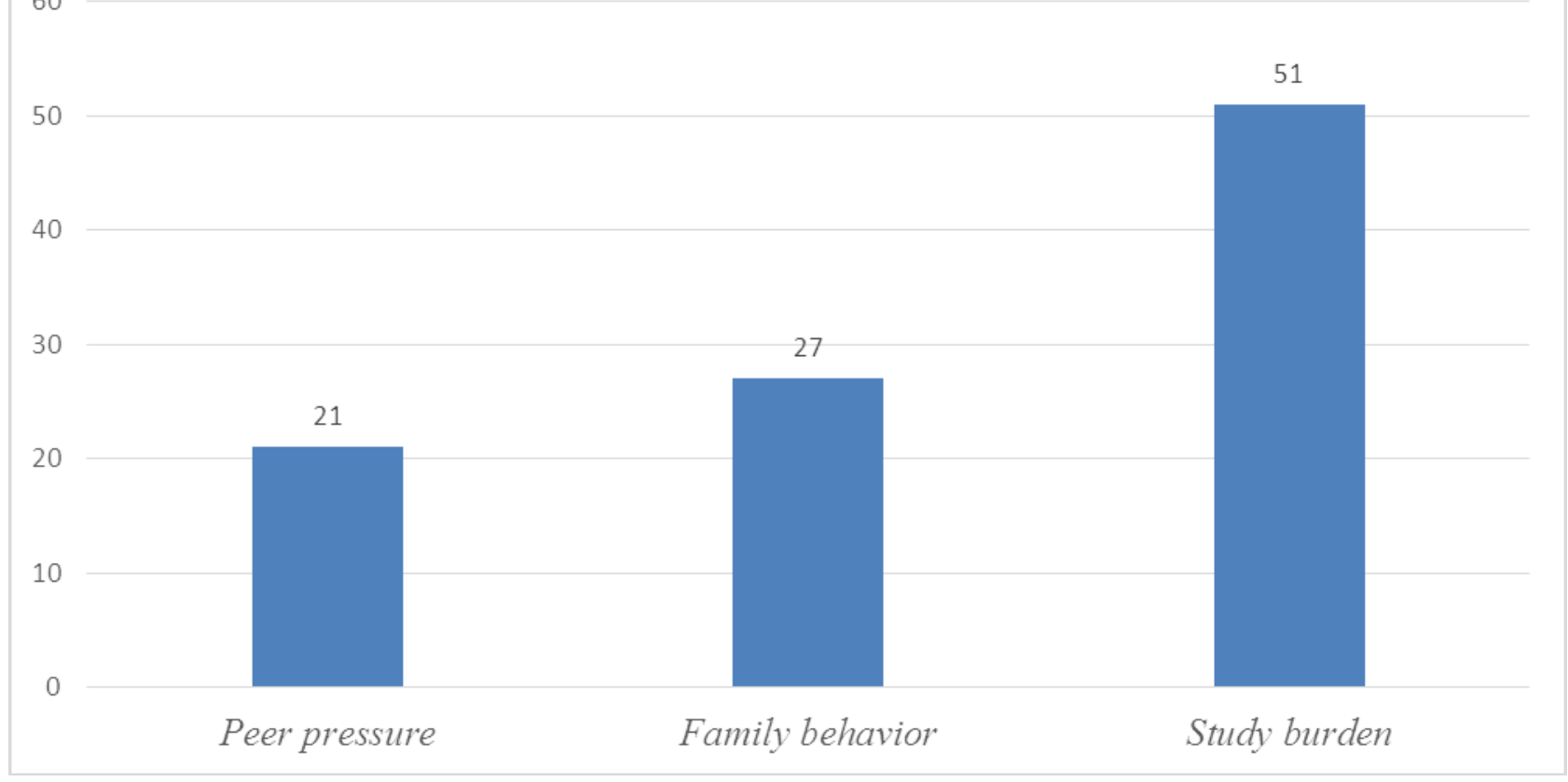

Figure 4.6.

Table 4.7. Frequency and percentage of BMI (Body Description)

\begin{tabular}{llllllllllll}
\hline \multirow{2}{*}{ Variable } & \multicolumn{2}{c}{$\begin{array}{l}\text { Marginally } \\
\text { overweight }\end{array}$} & \multicolumn{2}{c}{ Overweight } & Obese & \multicolumn{2}{c}{ Normal } & \multicolumn{2}{c}{ Underweight } \\
\cline { 2 - 11 } & f & $\mathbf{\%}$ & $\mathbf{f}$ & $\mathbf{\%}$ & $\mathbf{f}$ & $\mathbf{\%}$ & $\mathbf{f}$ & $\mathbf{\%}$ & $\mathbf{f}$ & $\mathbf{\%}$ \\
\hline Body Description & 15 & 7.5 & 17 & 8.5 & 4 & 2 & 134 & 67 & 30 & 15 \\
\hline
\end{tabular}

\section{Interpretation}

Out of 200 students almost $8 \%$ students are marginally overweight according to their BMI. The $9 \%$ students are overweight, only $2 \%$ students are obese in the context to BMI. Out of total number of students $67 \%$ students are normal in their body description and $15 \%$ students are underweight according to their BMI. So it is concluded that majority of students are normal in their body description according to their BMI. 


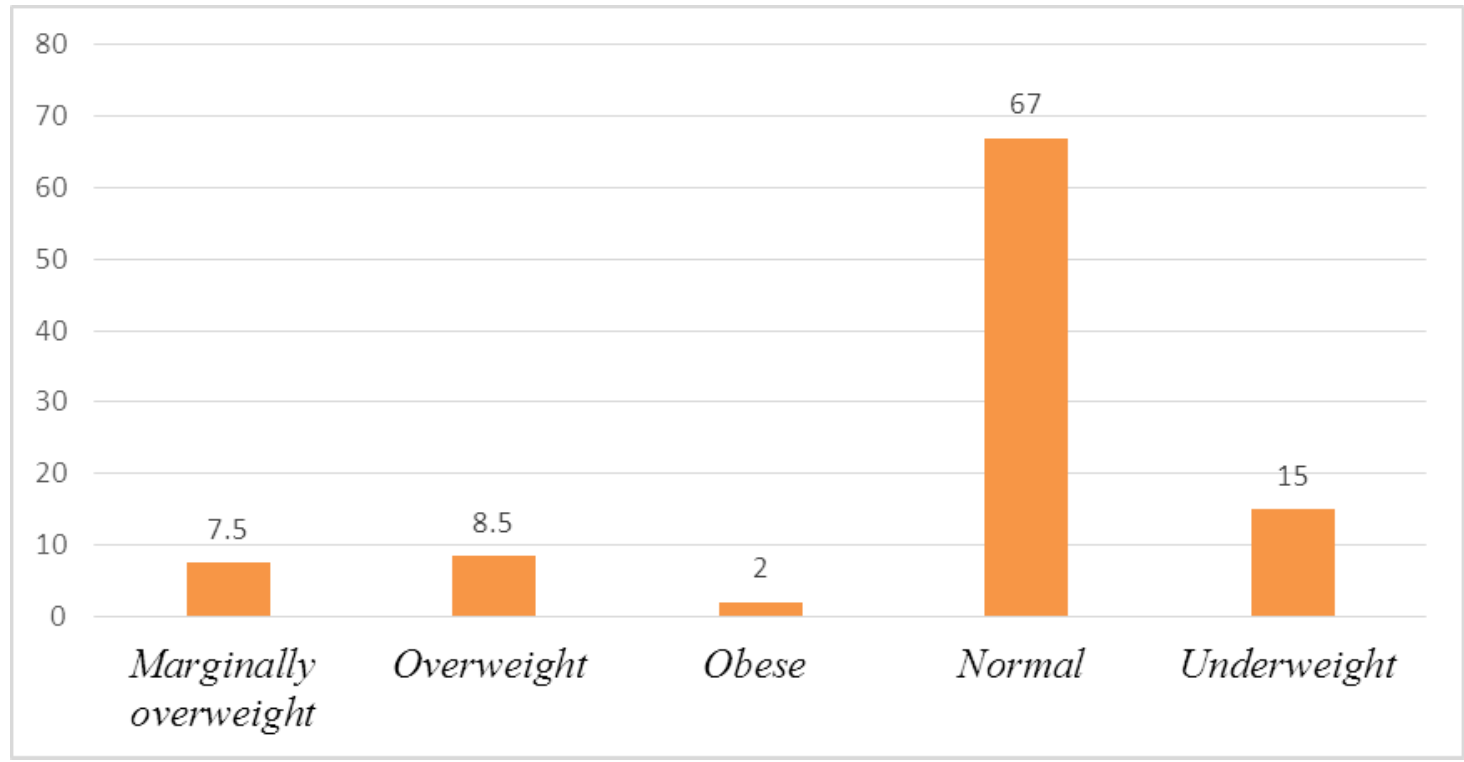

Figure 4.7.

Table 4.8. Difference between living style of male and female

\begin{tabular}{|c|c|c|c|c|c|c|}
\hline \multirow{2}{*}{ Living Style } & \multicolumn{2}{|c|}{ Female } & \multicolumn{2}{|c|}{ Male } & \multirow{2}{*}{$\mathbf{t}$} & \multirow{2}{*}{$\mathbf{p}$} \\
\hline & $\mathbf{M}$ & SD & $\mathbf{M}$ & SD & & \\
\hline $\begin{array}{l}\text { Do you help family member in doing } \\
\text { household tasks? }\end{array}$ & 2.43 & 0.79 & 2.54 & 0.63 & 1.09 & .278 \\
\hline $\begin{array}{l}\text { Do you take meal (lunch/dinner) with } \\
\text { family? }\end{array}$ & 2.62 & 0.69 & 2.57 & 0.70 & 0.51 & .612 \\
\hline Do you attend family functions? & 2.74 & 0.58 & 2.71 & 0.57 & 0.37 & .713 \\
\hline Do you attend University functions? & 2.36 & 0.77 & 2.65 & 0.59 & 2.98 & $.003 *$ \\
\hline $\begin{array}{l}\text { Do you prefer to hanging out with your } \\
\text { friend? }\end{array}$ & 2.62 & 0.62 & 2.57 & 0.70 & 0.54 & .592 \\
\hline $\begin{array}{l}\text { Do you get conscious about your } \\
\text { clothes? }\end{array}$ & 2.49 & 0.72 & 2.27 & 0.81 & 2.03 & $.044^{*}$ \\
\hline Are you brand conscious? & 1.89 & 0.87 & 2.06 & 0.92 & 1.34 & .182 \\
\hline Do you in favor of early marriages? & 1.72 & 0.90 & 2.04 & 0.95 & 2.44 & $.015^{*}$ \\
\hline
\end{tabular}

\section{Interpretation}

Independent samples t-test was conducted to see the difference between male and female regarding their living style. The criteria for significance is .05 . There is statistically significant difference in male and female students in some aspects of living style because their $\mathrm{p}$ value is less than 0.5 . The mean of female students $(\mathrm{M}=2.36, \mathrm{SD}=0.77)$ shows less interest in attending university functions than the mean of male students $(\mathrm{M}=2.65, \mathrm{SD}=0.59)$. 


\section{I Macrothink}

Journal of Asian Development

ISSN 2377-9594 2018, Vol. 4, No. 1

The mean of female students $(\mathrm{M}=2.49, \mathrm{SD}=0.72)$ are more conscious about their clothes than the mean of male students $(\mathrm{M}=2.27, \mathrm{SD}=0.81)$. The mean of male students $(\mathrm{M}=2.04$, $\mathrm{SD}=0.95)$ highly in favor of early marriages than the mean of female students $(\mathrm{M}=1.72$, $\mathrm{SD}=0.90)$.

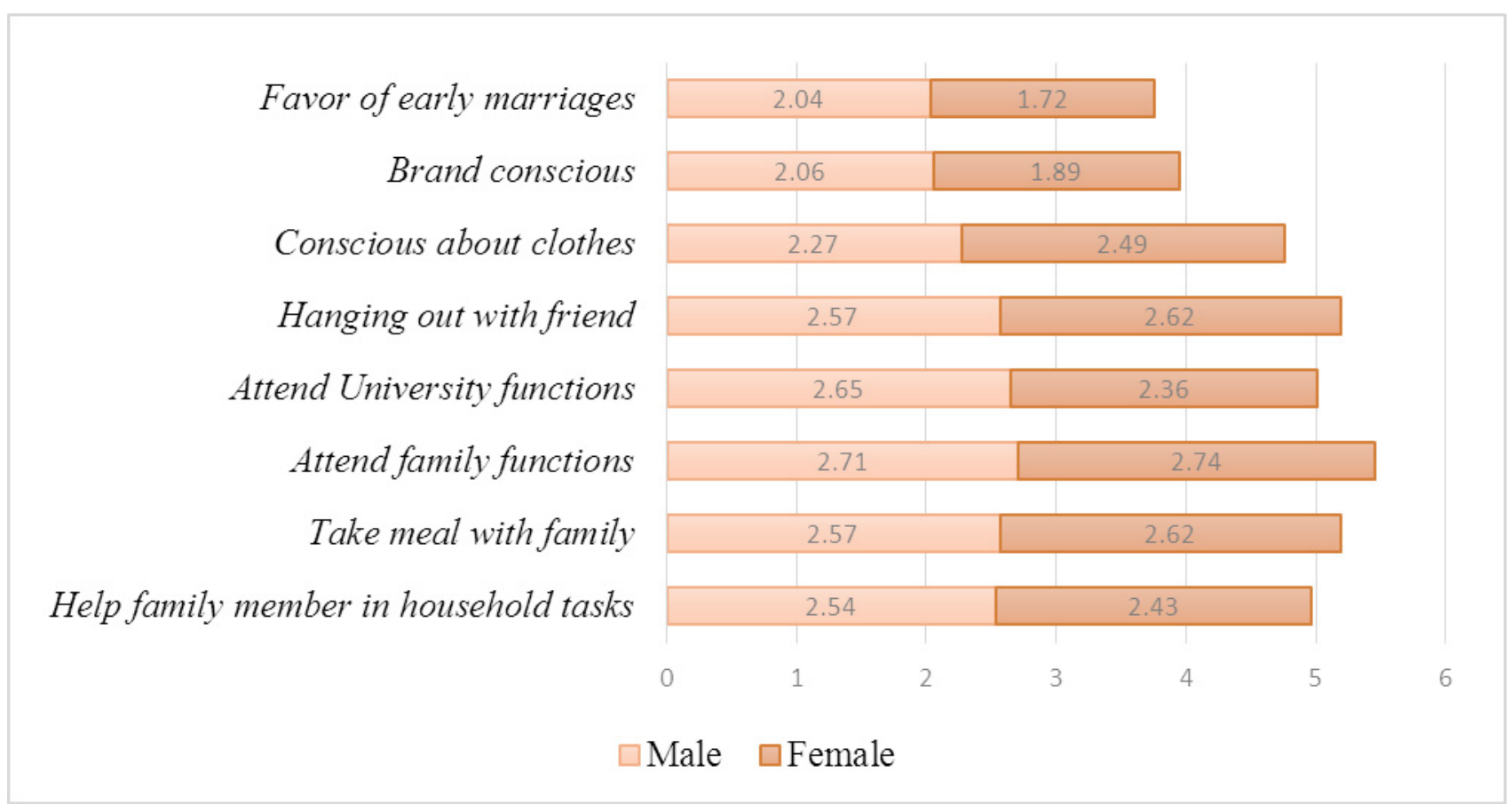

Figure 4.8.

Table 4.9. Difference between nutritional habits of male and female

\begin{tabular}{|c|c|c|c|c|c|c|}
\hline \multirow{2}{*}{ Nutritional Habits } & \multicolumn{2}{|c|}{ Female } & \multicolumn{2}{|c|}{ Male } & \multirow{2}{*}{$\mathbf{t}$} & \multirow{2}{*}{$\mathbf{p}$} \\
\hline & $\mathbf{M}$ & SD & $\mathbf{M}$ & SD & & \\
\hline Do you take breakfast regularly? & 2.07 & 0.93 & 2.28 & 0.88 & 1.64 & .103 \\
\hline Do you skip any meal? & 2.22 & 0.85 & 2.11 & 0.79 & 0.95 & .344 \\
\hline Do you engage in activities while eating? & 2.47 & 0.73 & 2.20 & 0.86 & 2.38 & $.018^{*}$ \\
\hline You eat more when you are anxious, worried or tense? & 1.74 & 0.88 & 1.58 & 0.83 & 1.32 & .189 \\
\hline
\end{tabular}

\section{Interpretation}

Independent samples t-test was conducted to see the difference between male and female students regarding their nutritional habits. The criteria for significance is .05 . There is statistically significant difference in male and female students in some aspects of nutritional habits because their $\mathrm{p}$ value is less than .05 . The criteria for significance is .05 . The mean of female students $(M=2.47, \mathrm{SD}=0.73)$ are more engage in activities while eating than the mean of male students $(\mathrm{M}=2.20, \mathrm{SD}=0.86)$. 


\section{Macrothink}

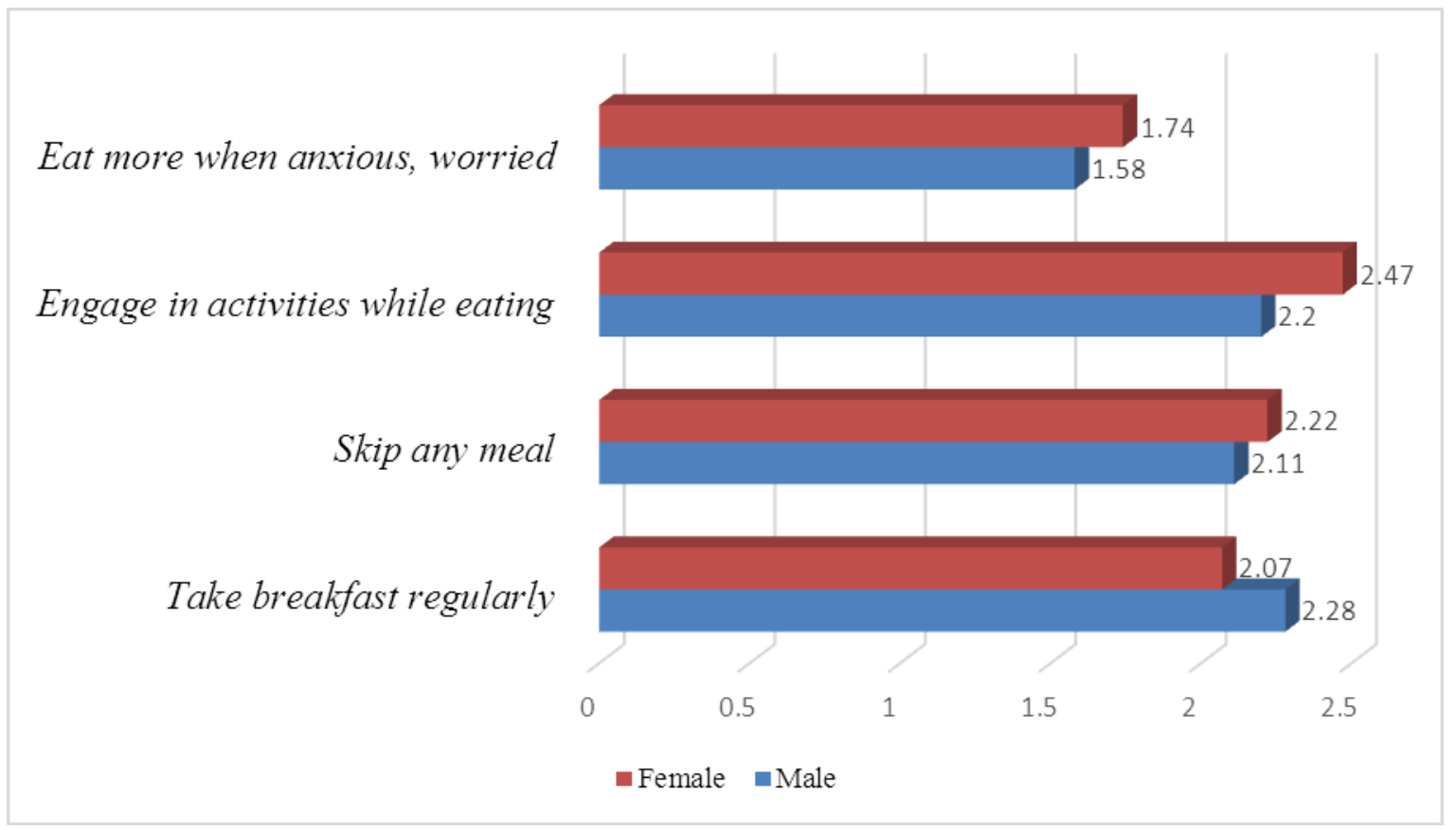

Figure 4.9.

Table 4.10. Difference between physical activity of male and female

\begin{tabular}{|c|c|c|c|c|c|c|}
\hline \multirow{2}{*}{ Physical Activity } & \multicolumn{2}{|c|}{ Female } & \multicolumn{2}{|c|}{ Male } & \multirow{2}{*}{$\mathbf{t}$} & \multirow{2}{*}{$\mathbf{p}$} \\
\hline & $\mathbf{M}$ & SD & $\overline{\mathbf{M}}$ & SD & & \\
\hline Do you enjoy being physically active? & 2.71 & 0.62 & 2.87 & 0.39 & -2.17 & $.031 *$ \\
\hline Do you engage in sports? & 1.75 & 0.83 & 2.54 & 0.73 & -7.13 & $.000^{*}$ \\
\hline Would you like to do gym? & 2.00 & 0.94 & 2.41 & 0.81 & -3.31 & $.001 *$ \\
\hline Are you engage in swimming? & 1.28 & 0.62 & 1.74 & 0.87 & -4.30 & $.000 *$ \\
\hline Do you engage in walk (evening/morning)? & 2.00 & 0.82 & 2.35 & 0.833 & 2.98 & $.003 *$ \\
\hline
\end{tabular}

\section{Interpretation}

Independent samples t-test was conducted to see the difference between male and female students regarding their physical activity. The criteria for significance is .05 . There is statistically significant difference in male and female students in some aspects of physical activity because their $\mathrm{p}$ value is less than .05 . The mean of male students $(\mathrm{M}=2.87, \mathrm{SD}=0.39)$ are enjoy physically active more than the mean of female students $(\mathrm{M}=2.71, \mathrm{SD}=0.62)$. The mean of male students $(\mathrm{M}=2.54, \mathrm{SD}=0.73)$ engage in sports than the mean of female students $(\mathrm{M}=1.75, \mathrm{SD}=0.83)$. The mean of female students $(\mathrm{M}=2.00, \mathrm{SD}=0.94)$ are less involve in gym than the mean of male students $(\mathrm{M}=2.41, \mathrm{SD}=0.81)$. The mean of male students $(\mathrm{M}=$ $1.74, \mathrm{SD}=0.87)$ are more engage in swimming than the mean of female students $(\mathrm{M}=1.28$, $\mathrm{SD}=0.62)$. The mean of male students $(\mathrm{M}=2.35, \mathrm{SD}=0.833)$ are more engage in morning or evening walk than the mean of females students $(\mathrm{M}=2.00, \mathrm{SD}=0.82)$. 


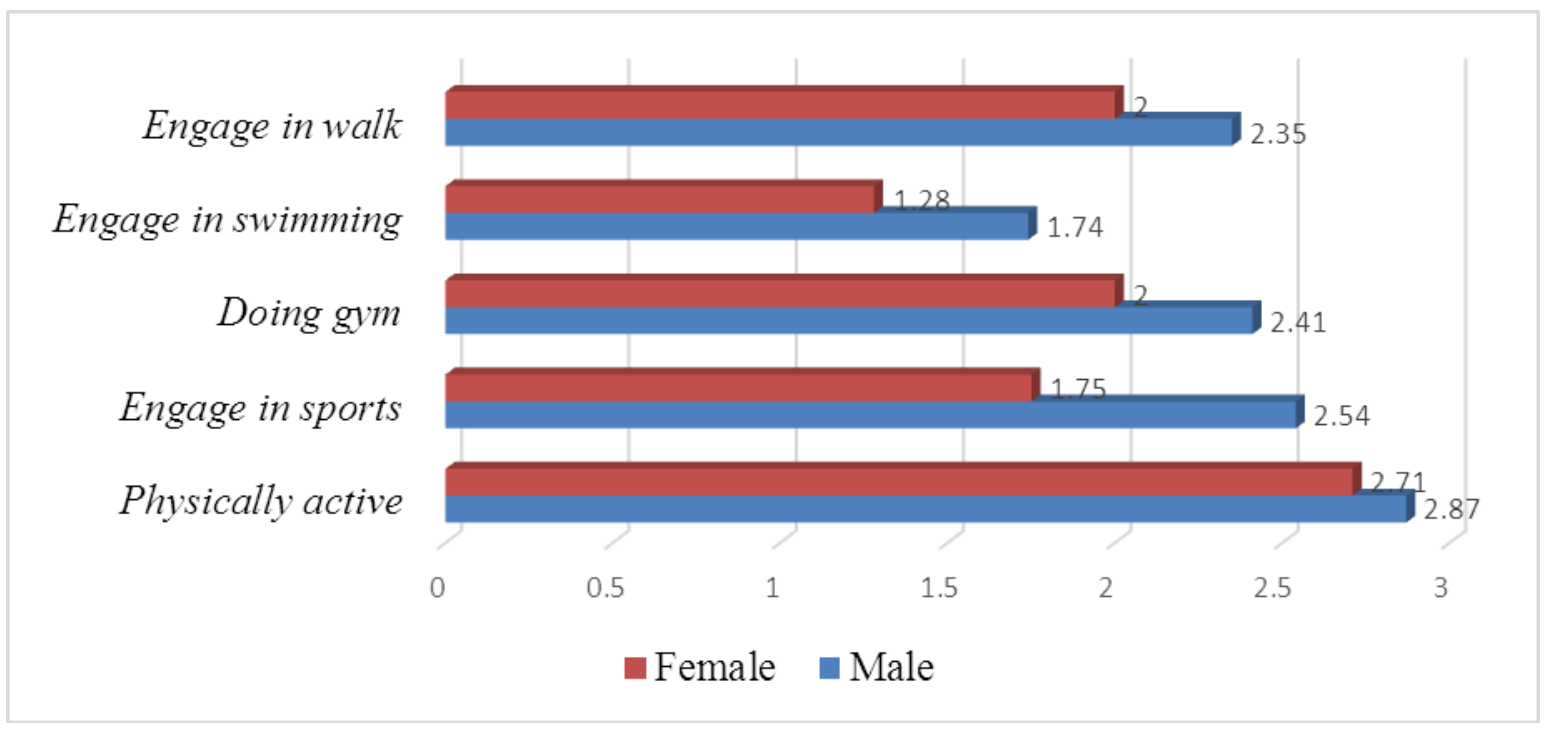

Figure 4.10.

Table 4.11. Difference between weight management of male and female.

\begin{tabular}{|c|c|c|c|c|c|c|}
\hline \multirow{2}{*}{ Weight Management } & \multicolumn{2}{|c|}{ Female } & \multicolumn{2}{|c|}{ Male } & \multirow{2}{*}{$\mathbf{t}$} & \multirow{2}{*}{$\mathbf{p}$} \\
\hline & $\mathbf{M}$ & SD & $\mathbf{M}$ & SD & & \\
\hline Do you consider yourself overweight? & 1.75 & 0.91 & 1.47 & 0.78 & 2.32 & $.021 *$ \\
\hline Is anyone in your family overweight? & 2.19 & 0.97 & 1.81 & 0.96 & 2.78 & $.006^{*}$ \\
\hline $\begin{array}{l}\text { I count calories as a conscious means of } \\
\text { controlling my weight. }\end{array}$ & 1.68 & 0.80 & 1.82 & 0.82 & -1.22 & .224 \\
\hline $\begin{array}{l}\text { Are you using extra supplements for muscles } \\
\text { building or weight reducing? }\end{array}$ & 1.17 & 0.51 & 1.41 & 0.79 & -2.54 & $.012 *$ \\
\hline
\end{tabular}

\section{Interpretation}

Independent samples t-test was conducted to see the difference between male and female students related to their weight management. The criteria for significance is .05 . There is statistically significant difference in male and female students in some aspects of weight management because their $p$ value is less than 0.5 . The mean of female students $(M=1.75$, $\mathrm{SD}=0.91)$ more consider their self overweight than the mean of male students $(\mathrm{M}=1.47$, $\mathrm{SD}=0.78)$. The mean of female students $(\mathrm{M}=2.19, \mathrm{SD}=0.97)$ have more overweight family members than the mean of male students $(\mathrm{M}=1.81, \mathrm{SD}=0.96)$. The mean of male students $(\mathrm{M}=1.41, \mathrm{SD}=0.79)$ highly use extra supplements for muscles building or weight reduces than the mean of female students $(\mathrm{M}=1.17, \mathrm{SD}=0.51)$. 


\section{Use extra supplements}

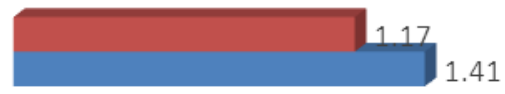

Count calories as for controlling weight.

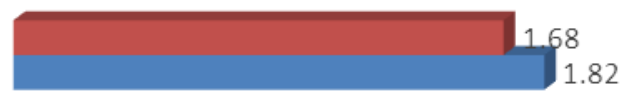

Anyone in family overweight

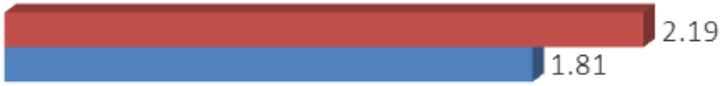

Consider yourself overweight

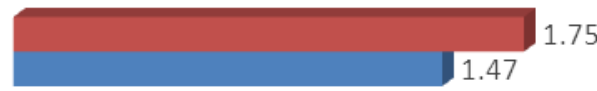

$\begin{array}{llllll}0 & 0.5 & 1 & 1.5 & 2 & 2.5\end{array}$

-Female $\square$ Male

Figure 4.11.

Table 4.12. Difference between sleeping habits of male and female

\begin{tabular}{|c|c|c|c|c|c|c|}
\hline \multirow{2}{*}{ Sleeping Habits } & \multicolumn{2}{|c|}{ Female } & \multicolumn{2}{|c|}{ Male } & \multirow{2}{*}{$\mathbf{t}$} & \multirow{2}{*}{$\mathbf{p}$} \\
\hline & $\mathbf{M}$ & SD & $\mathbf{M}$ & SD & & \\
\hline Do you often feel tired during the day? & 2.66 & 0.59 & 2.36 & 0.75 & 3.16 & $.002 *$ \\
\hline Do you have trouble while sleeping at night? & 1.82 & 0.86 & 1.71 & 0.86 & 0.91 & .365 \\
\hline Do you sleep/wakeup late at weekend? & 2.34 & 0.81 & 2.51 & 0.73 & -1.56 & .120 \\
\hline Do you study late night? & 1.99 & 0.90 & 1.99 & 0.82 & 0.00 & 1.000 \\
\hline
\end{tabular}

\section{Interpretation}

Independent samples t-test was conducted to see the difference between male and female students related to their sleeping habits. The criteria for significance is .05 . There is statistically significant difference in male and female students in some aspects of sleep patterns because their $\mathrm{p}$ value is less than .05 . Mostly the mean of females respondents $(\mathrm{M}=2.66, \mathrm{SD}=0.59)$ feel tired during the day than the mean of male respondents $(\mathrm{M}=2.36$, $\mathrm{SD}=0.75)$. 


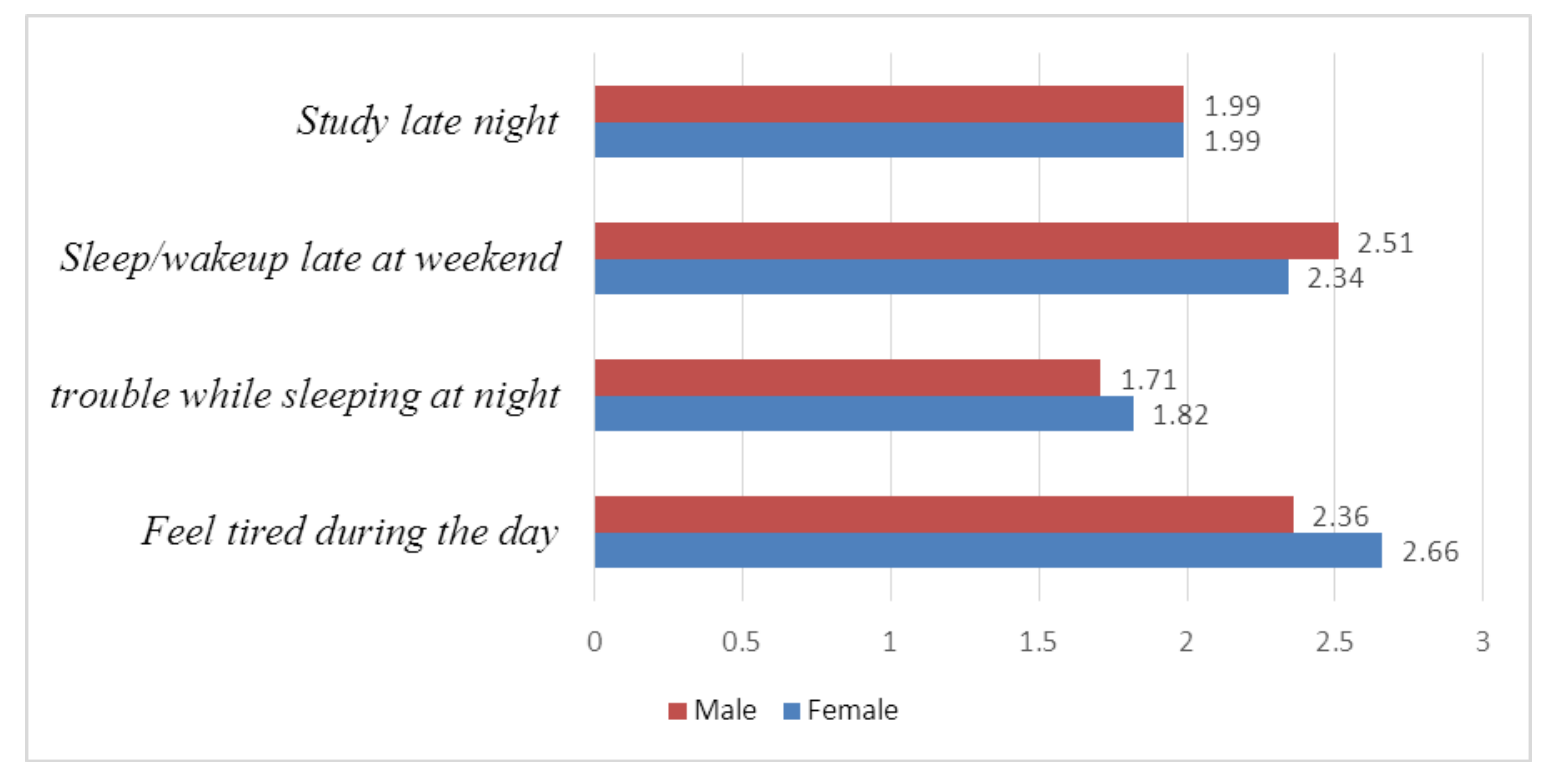

Figure 4.12.

Table 4.13. Difference between stress management of male and female

\begin{tabular}{|c|c|c|c|c|c|c|}
\hline \multirow{2}{*}{ Stress Management } & \multicolumn{2}{|c|}{ Female } & \multicolumn{2}{|c|}{ Male } & \multirow{2}{*}{$\mathbf{t}$} & \multirow{2}{*}{$\mathbf{p}$} \\
\hline & $\mathbf{M}$ & SD & $\mathbf{M}$ & SD & & \\
\hline Do you feel stressed? & 2.40 & 0.75 & 2.16 & 0.80 & 2.19 & $.030^{*}$ \\
\hline Do you think you manage your stress? & 2.16 & 0.81 & 2.45 & 0.77 & -2.59 & $.010^{*}$ \\
\hline Do you think you are able to control irritations in your life? & 2.41 & 0.71 & 2.46 & 0.74 & -0.49 & .628 \\
\hline $\begin{array}{l}\text { Do you think you become stressful due to unexpected happening in } \\
\text { life? }\end{array}$ & 2.21 & 0.78 & 2.03 & 0.76 & 1.65 & .100 \\
\hline
\end{tabular}

\section{Interpretation}

Independent samples t-test was conducted to see the difference between male and female students regarding their stress management skills. The criteria for significance is .05 . There is statistically significant difference in male and female students in some aspects of stress management because their $p$ value is less than .05 . The mean of male students $(M=2.16$, $\mathrm{SD}=0.80)$ are less feel stress than the mean of female students $(\mathrm{M}=2.40, \mathrm{SD}=0.75)$. Mostly the mean of male students $(\mathrm{M}=2.45, \mathrm{SD}=0.77)$ think they manage their stress well than the mean of female students $(\mathrm{M}=2.16, \mathrm{SD}=0.81)$. 


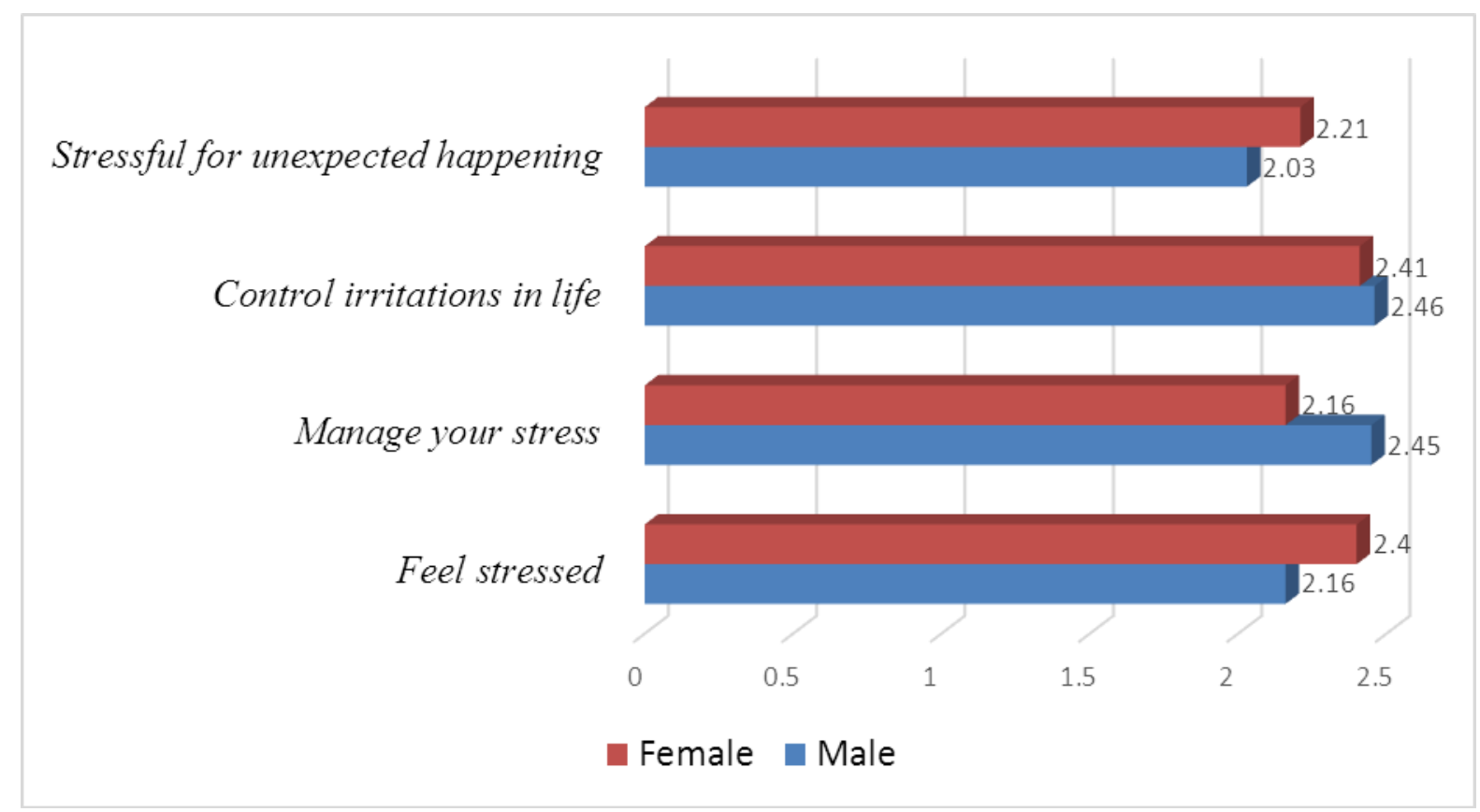

Figure 4.13.

Table 4.14. Difference between time management of male and female

\begin{tabular}{|c|c|c|c|c|c|c|}
\hline \multirow[b]{2}{*}{ Time Management } & \multicolumn{2}{|c|}{ Female } & \multicolumn{2}{|c|}{ Male } & \multirow[t]{2}{*}{$\bar{t}$} & \multirow[t]{2}{*}{$\mathbf{p}$} \\
\hline & $\mathbf{M}$ & SD & $\mathbf{M}$ & SD & & \\
\hline Do you set your task for each day? & 1.70 & 0.76 & 1.90 & 0.85 & -1.76 & .080 \\
\hline Do you accomplish those task in time? & 1.97 & 0.81 & 2.03 & 0.85 & -0.51 & .609 \\
\hline Do you go late in class? & 1.53 & 0.74 & 1.89 & 0.86 & -3.16 & $.002 *$ \\
\hline $\begin{array}{l}\text { Do you miss deadlines for assignments, } \\
\text { presentations etc.? }\end{array}$ & 1.46 & 0.73 & 1.78 & 0.87 & -2.81 & $.005^{*}$ \\
\hline $\begin{array}{l}\text { Do you think your time management } \\
\text { skills are good? }\end{array}$ & 2.42 & 0.73 & 2.32 & 0.85 & 0.89 & .373 \\
\hline
\end{tabular}

\section{Interpretation}

Independent samples t-test was conducted. The criteria for significance is .05 . There is statistically significant difference in male and female students in some aspects of time management because their $\mathrm{p}$ value is less than .05. Majority of the mean of male students $(\mathrm{M}=1.90, \mathrm{SD}=0.85)$ are set their daily task more than the mean of female students $(\mathrm{M}=1.70$, $\mathrm{SD}=0.76)$. The mean of male students $(\mathrm{M}=1.89, \mathrm{SD}=0.86)$ are mostly go late in their classes than the mean of female students $(\mathrm{M}=1.53, \mathrm{SD}=0.74)$. The mean of females $(\mathrm{M}=1.46$, $\mathrm{SD}=0.73$ ) are less miss deadlines for their presentations, assignments etc. than the mean of male students $(\mathrm{M}=1.78, \mathrm{SD}=0.87)$. 


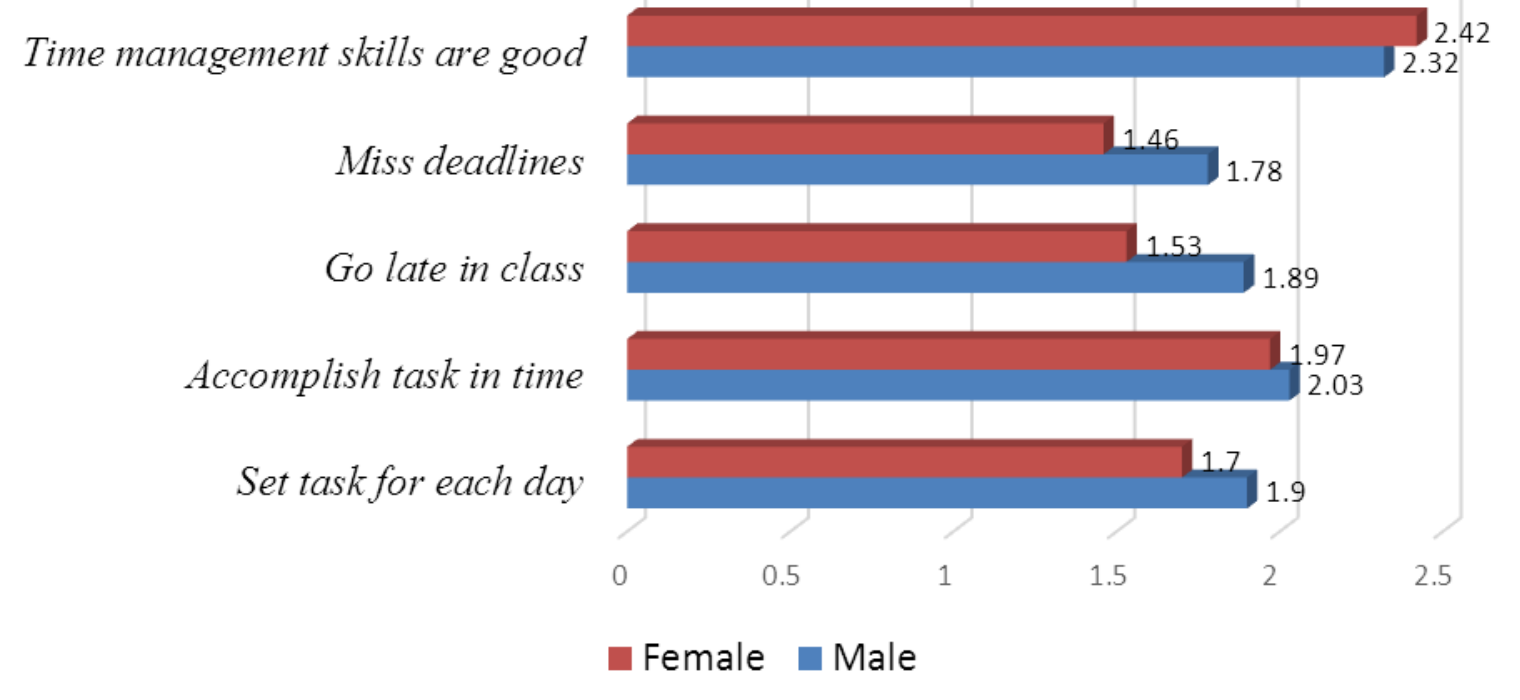

Figure 4.14.

Table 4.15. Difference between living style of private and public universities students

\begin{tabular}{|c|c|c|c|c|c|c|}
\hline \multirow[b]{2}{*}{ Living Style } & \multicolumn{2}{|c|}{ Public } & \multicolumn{2}{|c|}{ Private } & \multirow[t]{2}{*}{$\mathbf{t}$} & \multirow[t]{2}{*}{$\mathbf{p}$} \\
\hline & $\mathbf{M}$ & SD & $\mathbf{M}$ & SD & & \\
\hline $\begin{array}{l}\text { Do you help family member in } \\
\text { doing household tasks? }\end{array}$ & 2.56 & 0.67 & 2.41 & 0.76 & 1.44 & .152 \\
\hline $\begin{array}{l}\text { Do you take meal (lunch/dinner) } \\
\text { with family? }\end{array}$ & 2.68 & 0.60 & 2.51 & 0.77 & 1.78 & .076 \\
\hline Do you attend family functions? & 2.80 & 0.49 & 2.65 & 0.64 & 1.89 & .060 \\
\hline Do you attend University functions? & 2.71 & 0.57 & 2.29 & 0.76 & 4.37 & $.000^{*}$ \\
\hline $\begin{array}{l}\text { Do you prefer to hanging out with } \\
\text { your friend? }\end{array}$ & 2.53 & 0.72 & 2.66 & 0.59 & -1.36 & .176 \\
\hline $\begin{array}{l}\text { Do you get conscious about your } \\
\text { clothes? }\end{array}$ & 2.43 & 0.74 & 2.32 & 0.81 & 0.97 & .332 \\
\hline Are you brand conscious? & 2.09 & 0.90 & 1.85 & 0.88 & 1.91 & $.058^{*}$ \\
\hline Do you in favor of early marriages? & 1.89 & 0.94 & 1.86 & 0.94 & 0.24 & .814 \\
\hline
\end{tabular}

\section{Interpretation}

Independent samples t-test was conducted to see the difference between public and private universities students lifestyle behavioral patterns regarding to their living style. The criteria for significance is .05 . There is statistically significant difference in public and private universities students in some aspects of living style because their p value is less than .05 . The 


\section{Macrothink}

Journal of Asian Development

ISSN 2377-9594 2018, Vol. 4, No. 1

mean of public universities students $(\mathrm{M}=2.71, \mathrm{SD}=0.57)$ are more attend their university functions than the men of private university students $(\mathrm{M}=2.29, \mathrm{SD}=0.76)$. The mean of public university students $(\mathrm{M}=2.09, \mathrm{SD}=0.90)$ are more brand conscious than the mean of private university students $(\mathrm{M}=1.85, \mathrm{SD}=0.88)$.

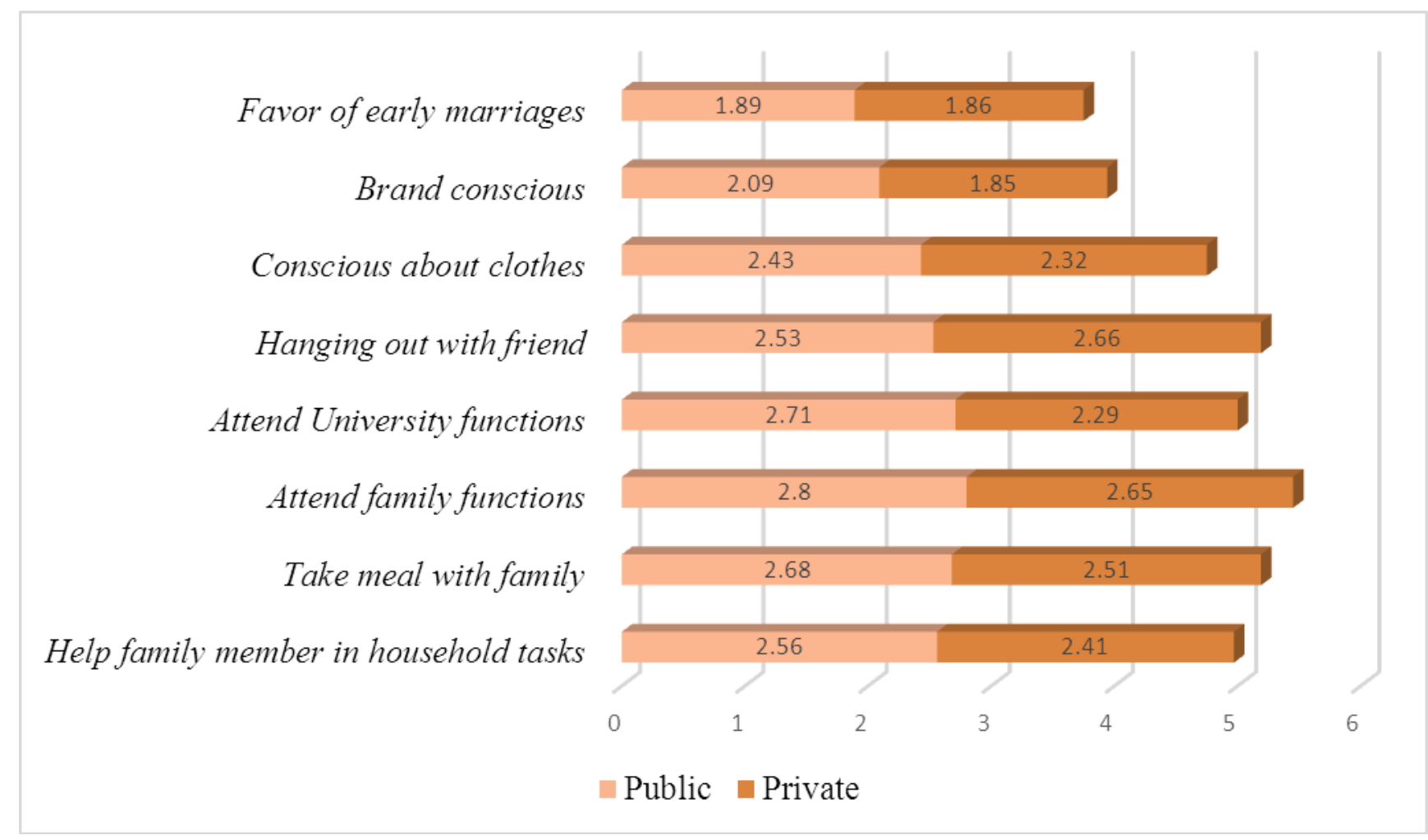

Figure 4.15.

Table 4.16. Difference between nutritional habits public and private universities students

\begin{tabular}{|c|c|c|c|c|c|c|}
\hline \multirow[b]{2}{*}{ Nutritional Habits } & \multicolumn{2}{|c|}{ Public } & \multicolumn{2}{|c|}{ Private } & \multirow[t]{2}{*}{ t } & \multirow[t]{2}{*}{$\mathbf{p}$} \\
\hline & M & SD & M & SD & & \\
\hline Do you take breakfast regularly? & 2.23 & 0.91 & 2.12 & 0.92 & 0.84 & .402 \\
\hline Do you skip any meal? & 2.23 & 0.79 & 2.09 & 0.85 & 1.20 & .232 \\
\hline $\begin{array}{l}\text { Do you engage in activities while } \\
\text { eating? }\end{array}$ & 2.26 & 0.80 & 2.40 & 0.82 & -1.26 & .211 \\
\hline $\begin{array}{l}\text { You eat more when you are } \\
\text { anxious, worried or tense? }\end{array}$ & 1.59 & 0.81 & 1.73 & 0.91 & -1.13 & .262 \\
\hline
\end{tabular}

\section{Interpretation}

Independent samples t-test was conducted to see the difference between public and private 


\section{Macrothink}

Journal of Asian Development

ISSN 2377-9594 2018, Vol. 4, No. 1

universities students lifestyle behavioral patterns regarding to their nutritional habits. The criteria for significance is .05 . There is no statistically significant difference in public and private universities students in some aspects of their nutritional habits because there $p$ value is greater than the .05 . $(\mathrm{P}>0.05)$

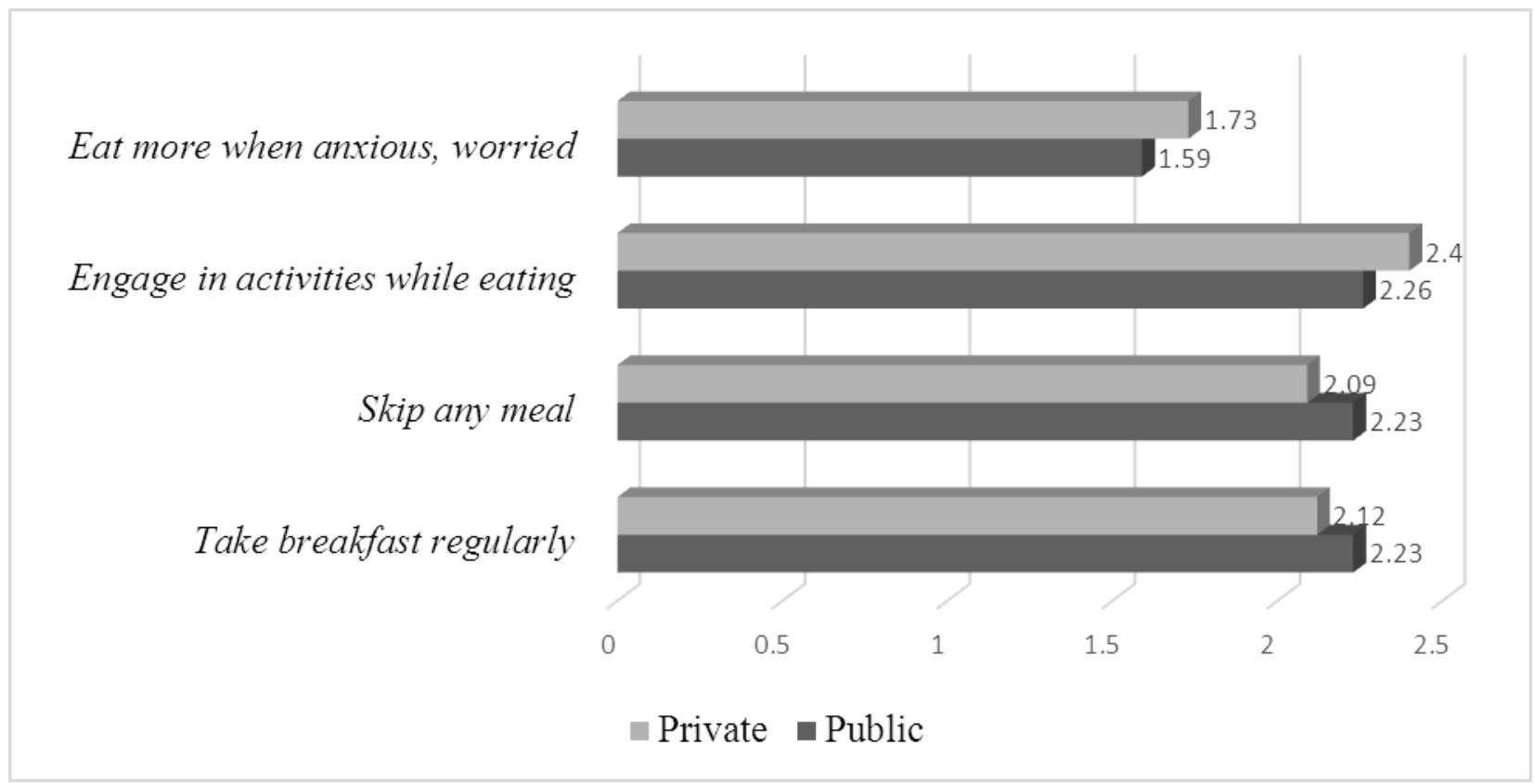

Figure 4.16.

Table 4.17. Difference between physical activity of public and private universities students

\begin{tabular}{|c|c|c|c|c|c|c|}
\hline \multirow[b]{2}{*}{ Physical Activity } & \multicolumn{2}{|c|}{ Public } & \multicolumn{2}{|c|}{ Private } & \multirow[t]{2}{*}{$\mathbf{t}$} & \multirow[t]{2}{*}{$\mathbf{p}$} \\
\hline & $\mathbf{M}$ & SD & $\mathbf{M}$ & SD & & \\
\hline $\begin{array}{l}\text { Do you enjoy being physically } \\
\text { active? }\end{array}$ & 2.81 & 0.49 & 2.78 & 0.56 & 0.43 & .666 \\
\hline $\begin{array}{l}\text { Do you engage in walk } \\
\text { (evening/morning)? }\end{array}$ & 2.22 & 0.82 & 2.13 & 0.88 & 0.74 & .463 \\
\hline Do you engage in sports? & 2.18 & 0.87 & 2.12 & 0.88 & 0.47 & .637 \\
\hline Would you like to do gym? & 2.12 & 0.92 & 2.28 & 0.87 & -1.28 & .202 \\
\hline Are you engage in swimming? & 1.49 & 0.78 & 1.54 & 0.80 & -0.40 & .687 \\
\hline
\end{tabular}

\section{Interpretation}

Independent samples t-test was conducted to see the difference between public and private universities students lifestyle behavioral patterns regarding to their physical activity. In the results of t-test there is no statistically significant difference in public and private universities students in some aspects of physical activity because there $\mathrm{p}$ value is greater than the .05 . 
Engage in swimming

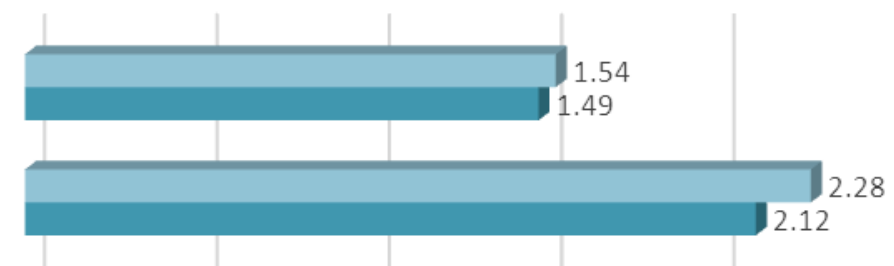

Engage in sports

Doing gym

Engage in walk

Physically active
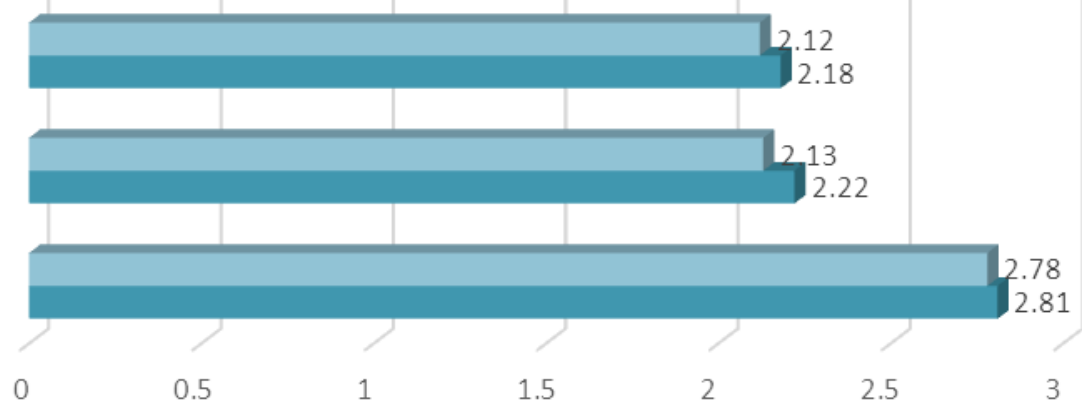

Private $\square$ Public

Figure 4.17.

Table 4.18. Difference between weight management of public and private universities students

\begin{tabular}{|c|c|c|c|c|c|c|}
\hline \multirow{2}{*}{ Weight Management } & \multicolumn{2}{|c|}{ Public } & \multicolumn{2}{|c|}{ Private } & \multirow{2}{*}{$\mathbf{t}$} & \multirow{2}{*}{$\mathbf{p}$} \\
\hline & $\mathbf{M}$ & SD & $\mathbf{M}$ & SD & & \\
\hline Do you consider yourself overweight? & 1.57 & 0.86 & 1.65 & 0.87 & -0.62 & .533 \\
\hline Is anyone in your family overweight? & 1.94 & 0.98 & 2.07 & 0.98 & -0.94 & .349 \\
\hline $\begin{array}{l}\text { I count calories as a conscious means } \\
\text { of controlling my weight. }\end{array}$ & 1.80 & 0.78 & 1.71 & 0.85 & 0.81 & .422 \\
\hline $\begin{array}{l}\text { Are you using extra supplements for } \\
\text { muscles building or weight reducing? }\end{array}$ & 1.26 & 0.65 & 1.30 & 0.69 & -0.45 & .651 \\
\hline
\end{tabular}

\section{Interpretation}

Independent samples t-test was conducted to see the difference between public and private universities students lifestyle behavioral patterns regarding to their weight management. The criteria for significance is .05 . There is no statistically significant difference in public and private universities students in some aspects of weight management because there $p$ value is garter than .05 in the result of t-test. 


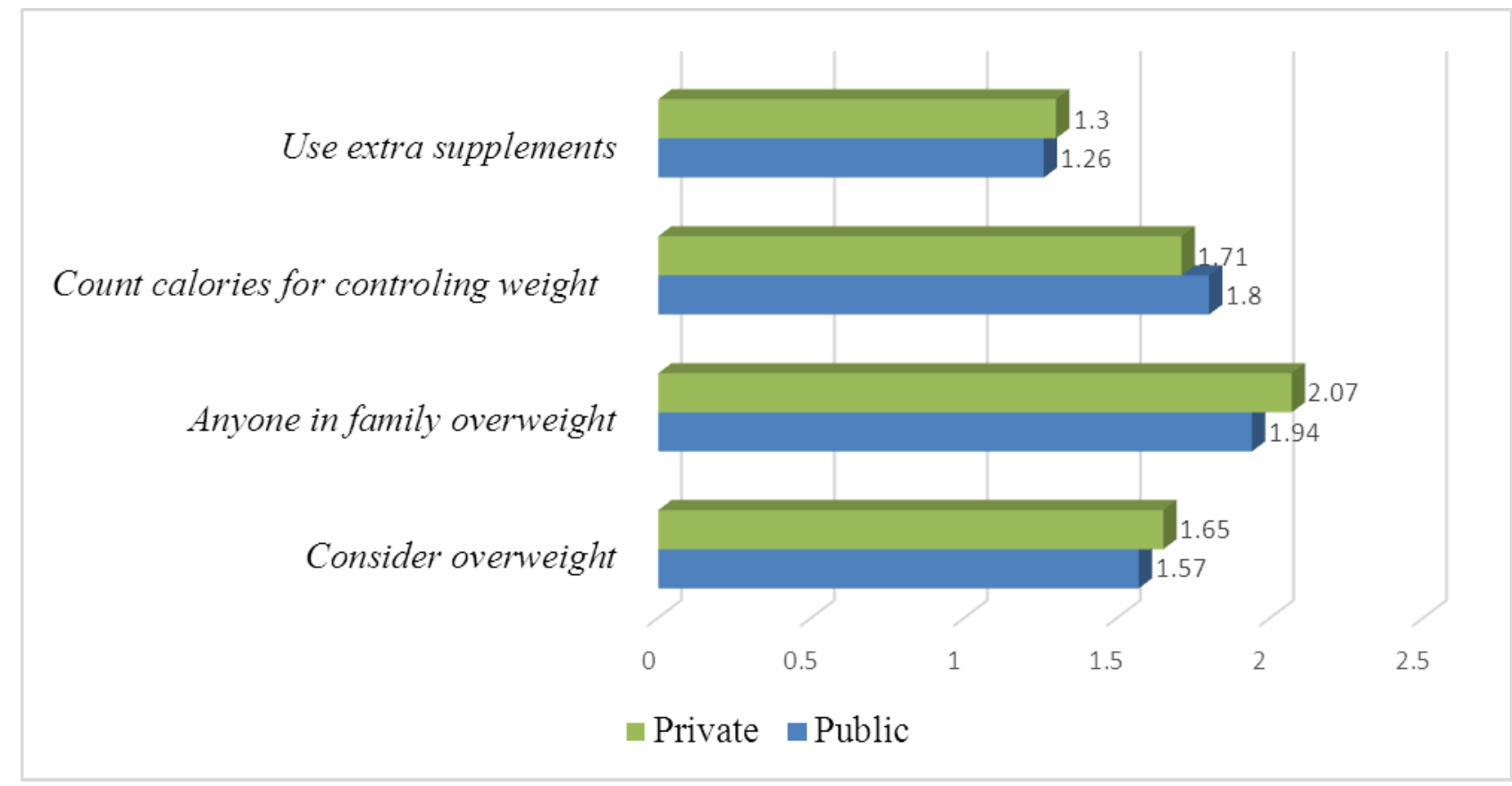

Figure 4.18.

Table 4.19. Difference between sleeping habits of public and private universities students

\begin{tabular}{|c|c|c|c|c|c|c|}
\hline \multirow{2}{*}{ Sleeping Habits } & \multicolumn{2}{|c|}{ Public } & \multicolumn{2}{|c|}{ Private } & \multirow{2}{*}{$\mathbf{t}$} & \multirow{2}{*}{$\mathbf{p}$} \\
\hline & M & SD & $\mathbf{M}$ & SD & & \\
\hline $\begin{array}{l}\text { Do you often feel tired during the } \\
\text { day? }\end{array}$ & 2.55 & 0.64 & 2.46 & 0.73 & 0.87 & .383 \\
\hline $\begin{array}{l}\text { Do you have trouble while sleeping } \\
\text { at night? }\end{array}$ & 1.65 & 0.81 & 1.87 & 0.89 & -1.82 & .071 \\
\hline $\begin{array}{l}\text { Do you sleep/wakeup late at } \\
\text { weekend? }\end{array}$ & 2.41 & 0.77 & 2.43 & 0.78 & -0.22 & .825 \\
\hline Do you study late night? & 1.93 & 0.87 & 2.05 & 0.86 & -0.98 & .327 \\
\hline
\end{tabular}

\section{Interpretation}

Independent samples t-test was conducted to see the difference between public and private universities students lifestyle behavioral patterns regarding to their sleeping habits. The criteria for significance is .05 . There is no statistically significant difference in public and private universities students in some aspects of sleeping habits because their $p$ value is greater than .05. There is all the values are doesn't fall in level of significance. 


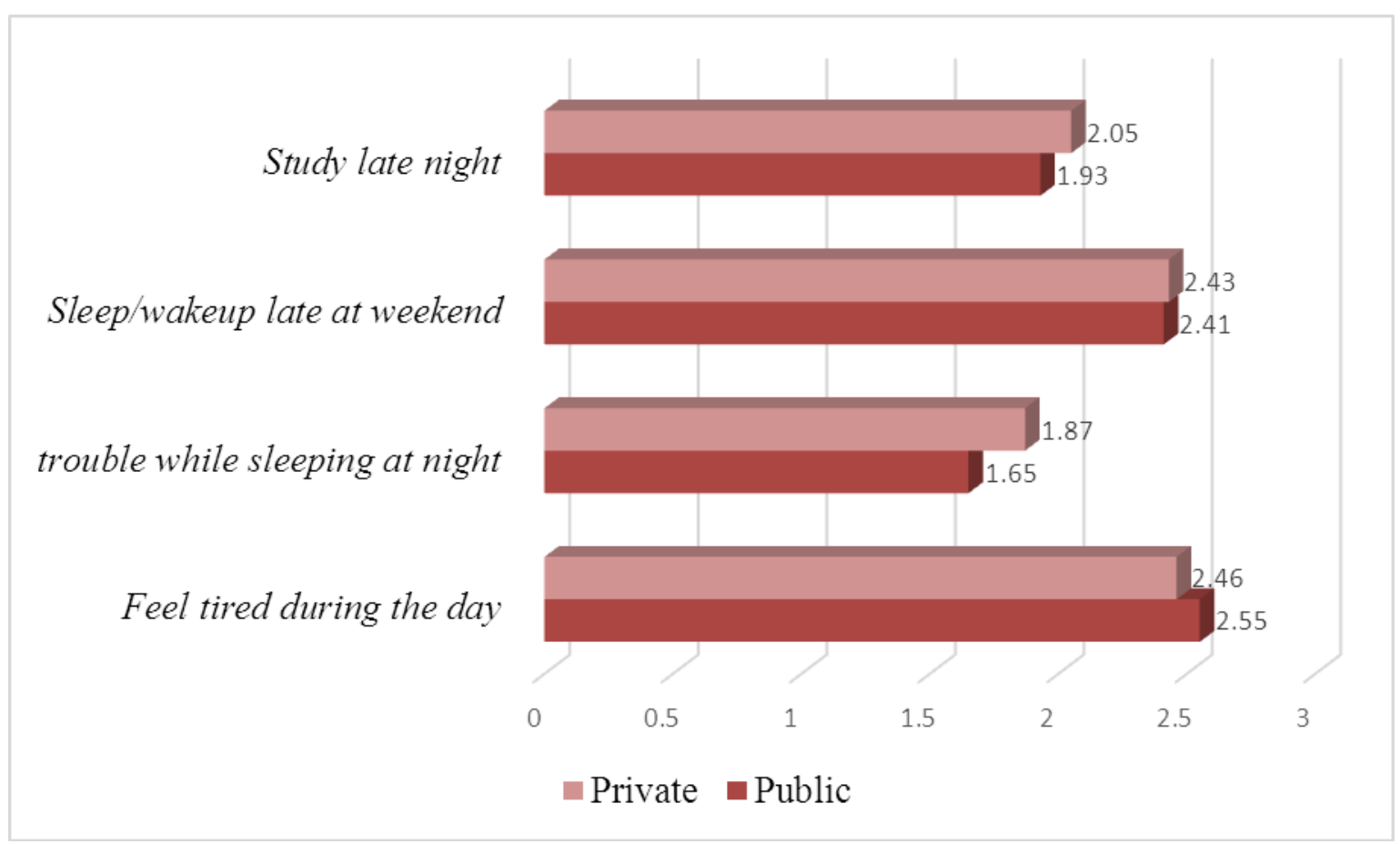

Figure 4.19.

Table 4.20. Difference between stress management of public and private universities students

\begin{tabular}{|c|c|c|c|c|c|c|}
\hline \multirow{2}{*}{ Stress Management } & \multicolumn{2}{|c|}{ Public } & \multicolumn{2}{|c|}{ Private } & \multirow{2}{*}{$\mathbf{t}$} & \multirow{2}{*}{$\mathbf{p}$} \\
\hline & $\mathbf{M}$ & SD & $\mathbf{M}$ & SD & & \\
\hline Do you feel stressed? & 2.25 & 0.83 & 2.31 & 0.74 & -0.57 & .572 \\
\hline $\begin{array}{l}\text { Do you think you manage your } \\
\text { stress? }\end{array}$ & 2.44 & 0.73 & 2.17 & 0.86 & 2.38 & $.018^{*}$ \\
\hline $\begin{array}{l}\text { Do you think you are able to control } \\
\text { irritations in your life? }\end{array}$ & 2.47 & 0.70 & 2.39 & 0.75 & 0.74 & .462 \\
\hline $\begin{array}{l}\text { Do you think you become stressful } \\
\text { due to unexpected happening in life? }\end{array}$ & 2.18 & 0.70 & 2.06 & 0.84 & 1.09 & .279 \\
\hline
\end{tabular}

\section{Interpretation}

Independent samples t-test was conducted to see the difference between public and private universities students lifestyle behavioral patterns regarding to their stress management skills. There is statistically significant difference in public and private universities students in some aspects of stress management because their $\mathrm{p}$ value is less than .05 . The mean of public university students $(\mathrm{M}=2.44, \mathrm{SD}=0.73)$ think they manage their stress well than the mean of private university students $(\mathrm{M}=2.17, \mathrm{SD}=0.86)$. 


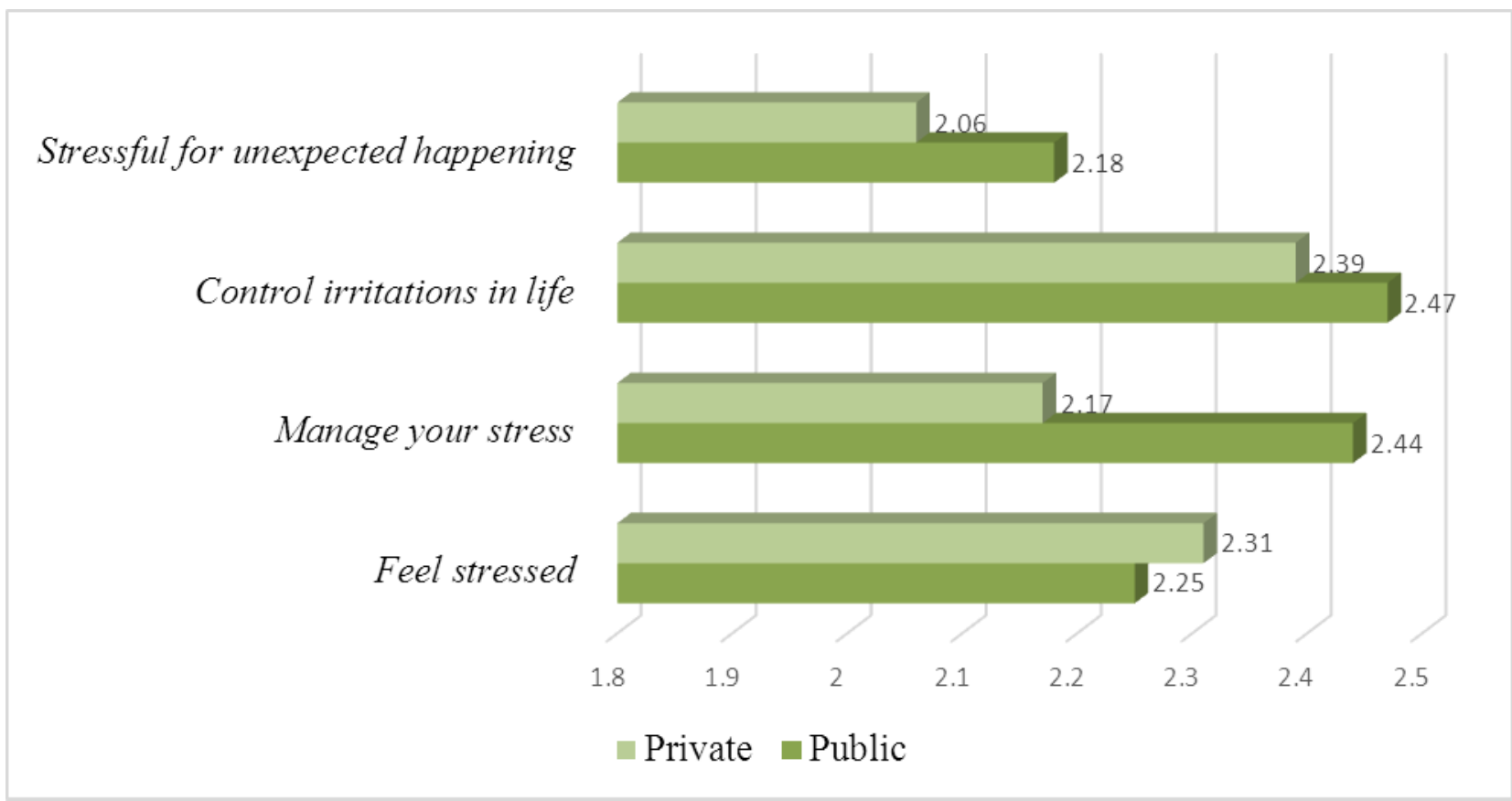

Figure 4.20.

Table 4.21. Difference between time management of public and private universities students

\begin{tabular}{|c|c|c|c|c|c|c|}
\hline \multirow{2}{*}{ Time Management } & \multicolumn{2}{|c|}{ Public } & \multicolumn{2}{|c|}{ Private } & \multirow{2}{*}{$\mathbf{t}$} & \multirow{2}{*}{$\mathbf{p}$} \\
\hline & $\mathbf{M}$ & SD & $\mathbf{M}$ & SD & & \\
\hline Do you set your task for each day? & 1.88 & 0.79 & 1.71 & 0.81 & 1.52 & .130 \\
\hline Do you accomplish those task in time? & 1.98 & 0.77 & 2.03 & 0.89 & -0.43 & .669 \\
\hline Do you go late in class? & 1.66 & 0.81 & 1.75 & 0.84 & -0.75 & .454 \\
\hline Do you miss deadlines for assignments, presentations etc.? & 1.60 & 0.80 & 1.65 & 0.84 & -0.40 & .690 \\
\hline Do you think your time management skills are good? & 2.46 & 0.76 & 2.27 & 0.82 & 1.68 & .095 \\
\hline
\end{tabular}

\section{Interpretation}

Independent samples t-test was conducted to see the difference between public and private universities students lifestyle behavioral patterns regarding to their time management. The criteria for significance is .05 . There is no statistically significant difference in public and private universities students in some aspects of time management. All $\mathrm{p}$ values are greater than the .05 . 
Time management skills are good
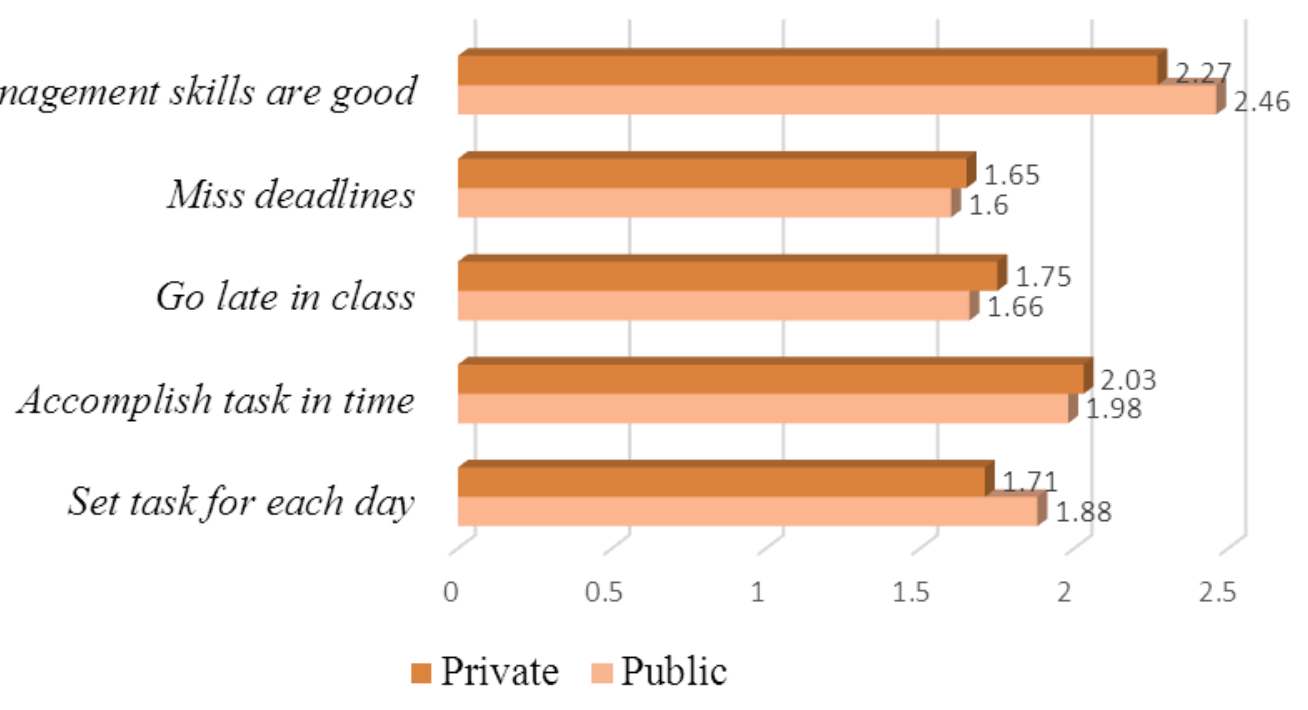

Figure 4.21 .

\section{Significant Findings}

1) Almost $49.5 \%$ students have joint family system. The $46.5 \%$ students of them prefer to live in joint family system. The $50.5 \%$ students have nuclear family system and $53.5 \%$ students of them wants to live in nuclear family system

2) The $31.3 \%$ students prefer nuclear family system and $68.7 \%$ students prefer same system. The $24.8 \%$ students prefer joint family system and $75.2 \%$ students prefer same system.

3) The $87 \%$ students helps their family member in house hold task.

4) Majority of students $88 \%$ students take meal with their family.

5) Almost $93 \%$ of students attend their family functions.

6) Majority of students $88 \%$ students attend their university functions.

7) Almost $90 \%$ of students prefer to hang out with their friends.

8) Approximately $82 \%$ of student's conscious about their clothes.

9) Almost 58\% students are brand conscious.

10) Total students $49 \%$ students are in favor of early marriages.

11) Out of 200 students $66 \%$ students takes breakfast regularly.

12) Almost $73 \%$ students skip their meals in routine.

13) Approximately $78 \%$ students engage in different activities while eating their meal.

14) The $40 \%$ students eat more when they are anxious, worried. 


\section{Macrothink}

15) Out of 200 students $94 \%$ students enjoy being physically active.

16) The majority of students $71 \%$ engage in walk.

17) Almost $67 \%$ students out of 200 engage in sports.

18) Out of 200 students approximately $68 \%$ students like to do gym.

19) The $32 \%$ students engage in swimming.

20) The $36 \%$ students consider their selves overweight.

21) Almost $52 \%$ students have any one overweight in their families.

22) The 51\% students count calories of their diet as a conscious mean of controlling their weight.

23) Out of 200 students almost 16\% students use extra supplements for muscles building and weight reducing.

24) The $89 \%$ students out of total students feel tired during the day.

25) Almost $49 \%$ students have trouble while sleeping at night.

26) Approximately $82 \%$ student's sleep/wakeup late at weekend.

27) Almost $62 \%$ students study late night.

28) Out of 200 students $79 \%$ students feel stressed.

29) Approximately $78 \%$ students think they manage their stress.

30) Almost $86 \%$ students think they are able to control irritations in their life.

31) Majority of students $75 \%$ think they become stress full due to unexpected happing in life.

32) The $55 \%$ students set their task for each day,

33) The $66 \%$ students accomplish their task in time.

34) Almost $47 \%$ students go late in their class.

35) Approximately $40 \%$ students miss deadlines for their assignments presentations.

36) Almost $80 \%$ students out of 200 students think their time management skills are good.

37) Total 31\% students consume 1-2 meals per day, Majority of students $54 \%$ consume $2-3$ meals per day while other $14 \%$ students consume per day.

38) Total $64 \%$ students get 6 to 8 hours sleep per night. Other $27 \%$ students get 8 to 9 hours sleep per night. Only $12 \%$ students get 9 to 10 hours sleep per night.

39) Total students $21 \%$ students have peer pressure as their major sources of stress. The $27 \%$ students have family behavior as their major source of stress. The $51 \%$ students 
have study burden as their major source of stress.

40) There is no statistically significant difference between male and female in some aspect of lifestyle behavioral patterns regarding to help family in household task, to take meal with family, to attend family functions, to hang out with friends and brand conscious. So the null hypothesis is partially accepted.

\section{Conclusion}

The main objective of research was to analyze lifestyle behavioral patterns among universities students. Lifestyle plays a significant role in the personality of students. It is appropriate to understand the connotation between personality and lifestyle of university students. To get the answer of research questions, researcher find out the difference between the lifestyle behavioral patterns of male and female students. The results shows that females are more interested to attended the university function and more conscious about their clothes than the male students. The male students more participated in different physical activities than the female students. The majority of male students use supplements for muscles building. The male students think they manage their stress well and they feel less stress than the female students. Female students less miss their deadlines for assignments and mostly go to their class on time than the male students.

The researcher also find out the difference between the public and private universities students lifestyle behavioral patterns. So the result showed that public university students $(\mathrm{M}=2.09, \mathrm{SD}=0.90)$ are more brand conscious than the mean of private university students $(\mathrm{M}=1.85, \mathrm{SD}=0.88)$, and they are more attend university function than the private university students. The public university students think they manage their stress well than the private university students.

BMI was calculated on the bases of weight, height, age and gender. So The $9 \%$ students are overweight, only $2 \%$ students are obese in the context to BMI. Out of total number of students $67 \%$ students are normal in their body description and $15 \%$ students are underweight according to their BMI. The research shows that the lifestyle patterns faithfully interconnected with nutritional habits, physical activity, weight management and BMI. Unhealthy food habits and physical inactivity affects the lifestyle patterns of students.

\section{Limitations}

- This study is limited to only one city Lahore.

- Only one university from public and one from private sector used for the data collection purpose.

- This study only focused on the lifestyle behavioral patterns and the differences between public and private universities students as well as gender differences.

\section{Recommendations}

- Comparable researches on students of different age groups should be conducted. 
- The researchers should also focus on family lifestyle behaviors.

- The future researchers should find out the lifestyle effects on personalities of student.

\section{References}

Bokareva, N. A., \& Skoblina, N. A. (2012). Effect of Modern Students' Lifestyle on their Physical Development.

Ceschini, F. L., Andrade, E. L. D., \& Figueira Júnior, A. (2015). Physical activity and associated factors among students attending evening classes. Revista Brasileira de Cineantropometria \& Desempenho Humano, 17(2), 205-215. https://doi.org/10.5007/1980-0037.2015v17n2p205

Foster - Schubert, K. E., Alfano, C. M., Duggan, C. R., Xiao, L., Campbell, K. L., Kong, A., ... \& McTiernan, A. (2012). Effect of diet and exercise, alone or combined, on weight and body composition in overweight - to - obese postmenopausal women. Obesity, 20(8), 1628-1638. https://doi.org/10.1038/oby.2011.76

Kassim, S., Jawad, M., Croucher, R., \& Akl, E. A. (2015). The epidemiology of tobacco use among khat users: a systematic review. BioMed research international, 2015. https://doi.org/10.1155/2015/313692

Lemma, S., Berhane, Y., Worku, A., Gelaye, B., \& Williams, M. A. (2014). Good quality sleep is associated with better academic performance among university students in Ethiopia. Sleep and Breathing, 18(2), 257-263. https://doi.org/10.1155/2012/583510

Sabbah, I., Sabbah, H., Khamis, R., Sabbah, S., \& Droubi, N. (2013). Health related quality of life of university students in Lebanon: Lifestyles behaviors and socio-demographic predictors. Health, 5(07), 1. https://doi.org/10.4236/health.2013.57A4001

Schmidt, M. (2012). Predictors of self-rated health and lifestyle behaviours in Swedish university students. Global journal of health science, 4(4), 1. https://doi.org/10.5539/gjhs.v4n4p1

Shochat, T. (2012). Impact of lifestyle and technology developments on sleep. Nature and science of sleep, 4, 19. https://doi.org/10.2147/NSS.S18891

Thirlaway, K., \& Upton, D. (2009). The Psychology of Lifestyle: promoting healthy behaviour. Routledge.

Wright, T. L. (2012). Body image and healthy lifestyle Behavior among University students.

Yang, H., He, F., Wang, T., Liu, Y., Shen, Y., Gong, J., ... \& Wang, T. (2015). Health-related lifestyle behaviors among male and female rural-to-urban migrant workers in Shanghai, China. PloS one, 10(2), e0117946. https://doi.org/10.1371/journal.pone.0117946 


\section{Macrothink

\section{Copyright Disclaimer}

Copyright for this article is retained by the author(s), with first publication rights granted to the journal.

This is an open-access article distributed under the terms and conditions of the Creative Commons Attribution license (http://creativecommons.org/licenses/by/4.0/). 